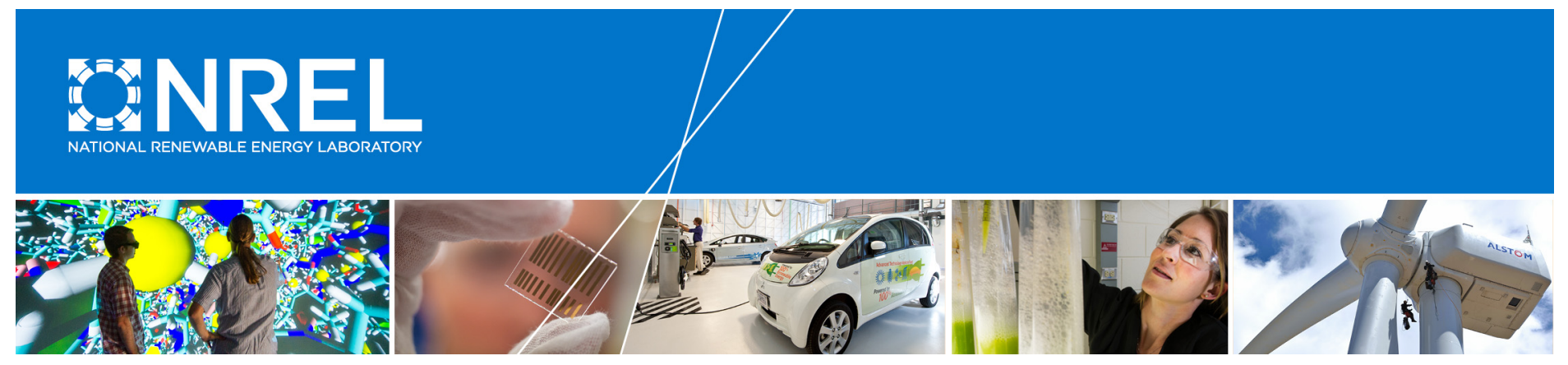

\title{
Impact of Research and Development, Analysis, and Standardization on PV Project Financing Costs
}

David Feldman, Rebecca Jones-Albertus, and Robert Margolis National Renewable Energy Laboratory

NREL is a national laboratory of the U.S. Department of Energy Office of Energy Efficiency \& Renewable Energy Operated by the Alliance for Sustainable Energy, LLC

This report is available at no cost from the National Renewable Energy Laboratory (NREL) at www.nrel.gov/publications.

Technical Report

NREL/TP-6A20-70939

April 2018 


\title{
Impact of Research and Development, Analysis, and Standardization on PV Project Financing Costs
}

\author{
David Feldman, Rebecca Jones-Albertus, \\ and Robert Margolis \\ National Renewable Energy Laboratory
}

\section{Suggested Citation}

Feldman, David, Rebecca Jones-Albertus, and Robert Margolis. 2018. Impact of Research and Development, Analysis, and Standardization on PV Project Financing Costs. Golden, CO: National Renewable Energy Laboratory. NREL/TP-6A20-70939.

https://www.nrel.gov/docs/fy18osti/70939.pdf.

NREL is a national laboratory of the U.S. Department of Energy Office of Energy Efficiency \& Renewable Energy Operated by the Alliance for Sustainable Energy, LLC

This report is available at no cost from the National Renewable Energy Laboratory (NREL) at www.nrel.gov/publications.

National Renewable Energy Laboratory 15013 Denver West Parkway Golden, CO 80401

303-275-3000 • www.nrel.gov

\section{Technical Report}

NREL/TP-6A20-70939

April 2018

Contract No. DE-AC36-08G028308 


\title{
NOTICE
}

This report was prepared as an account of work sponsored by an agency of the United States government. Neither the United States government nor any agency thereof, nor any of their employees, makes any warranty, express or implied, or assumes any legal liability or responsibility for the accuracy, completeness, or usefulness of any information, apparatus, product, or process disclosed, or represents that its use would not infringe privately owned rights. Reference herein to any specific commercial product, process, or service by trade name, trademark, manufacturer, or otherwise does not necessarily constitute or imply its endorsement, recommendation, or favoring by the United States government or any agency thereof. The views and opinions of authors expressed herein do not necessarily state or reflect those of the United States government or any agency thereof.

This report is available at no cost from the National Renewable Energy Laboratory (NREL) at www.nrel.gov/publications.

Available electronically at SciTech Connect http:/www.osti.gov/scitech

Available for a processing fee to U.S. Department of Energy and its contractors, in paper, from:

\author{
U.S. Department of Energy \\ Office of Scientific and Technical Information \\ P.O. Box 62 \\ Oak Ridge, TN 37831-0062 \\ OSTI http://www.osti.gov \\ Phone: 865.576.8401 \\ Fax: 865.576.5728 \\ Email: reports@osti.gov
}

Available for sale to the public, in paper, from:

\author{
U.S. Department of Commerce \\ National Technical Information Service \\ 5301 Shawnee Road \\ Alexandria, VA 22312 \\ NTIS http://www.ntis.gov \\ Phone: 800.553 .6847 or 703.605 .6000 \\ Fax: 703.605.6900 \\ Email: orders@ntis.gov
}




\section{Acknowledgments}

The authors appreciate the knowledgeable input and critical reviews provided by the following individuals, which greatly improved and informed the analysis: Paul Basore (formerly with DOE), Mark Bolinger (Lawrence Berkeley National Laboratory [LBNL]), Nat Eng (Novogradac), Kenneth Gillingham (Yale University), Henry Hieslmair (DNV GL), Jack Hoskins (DOE), Sarah Kurtz (NREL), Heidi Marie Larson (ICF), Jeffrey Logan (NREL), Marie Mapes (DOE), David Mooney (NREL), Jeffrey Newmiller (DNV GL), Garrett Nilsen (DOE), Dana Olson (DOE), Jon Previtali (Wells Fargo), Ammar Qusaibaty (DOE), David RenchMcCauley (DOE), Ralph Romero (Black \& Veatch), Mark Reusser (ICF), Paul Schwabe (NREL), Lenny Tinker (DOE), and Ryan Wiser (LBNL). The authors also thank Jarett Zuboy (consultant) and Mike Meshek (NREL) for editorial assistance.

This work was funded by the Solar Energy Technologies Office of the U.S. Department of Energy (DOE) Office of Energy Efficiency and Renewable Energy (EERE). 


\section{List of Acronyms}

$\begin{array}{ll}\text { ABS } & \text { Asset-backed securities } \\ \text { CAPM } & \text { Capital Asset Pricing Model } \\ \text { DOE } & \text { U.S. Department of Energy } \\ \text { DSCR } & \text { Debt service coverage ratio } \\ \text { IEC } & \text { International Electrotechnical Commission } \\ \text { IRR } & \text { Internal rate of return } \\ \text { KBRA } & \text { Kroll Bond Rating Agency } \\ \text { LCOE } & \text { Levelized cost of electricity } \\ \text { LIBOR } & \text { London Interbank Offered Rate } \\ \text { NREL } & \text { National Renewable Energy Laboratory } \\ \text { O\&M } & \text { Operations and maintenance } \\ \text { P50 } & \text { Average level of production } \\ \text { P99 } & \text { Production level from a project that has a 99\% } \\ & \text { chance of exceeding } \\ \text { PPA } & \text { Power-purchase agreement } \\ \text { PV } & \text { Photovoltaic } \\ \text { R\&D } & \text { Research and development } \\ \text { REIT } & \text { Real estate investment trust } \\ \text { SAM } & \text { System Advisor Model } \\ \text { SAPC } & \text { Solar Access to Public Capital (working group) } \\ \text { WACC } & \text { Weighted-average cost of capital }\end{array}$




\section{Executive Summary}

Recently, the U.S. Department of Energy set new targets for the levelized cost of electricity (LCOE) from solar photovoltaics (PV). For utility-scale PV systems without subsidies, the target is $3 \phi / \mathrm{kWh}$ by 2030 . Achieving these targets - which entails reducing costs by a factor of two to three from 2017 values - requires improvements in technology performance and reliability as well as reductions in hardware, operations and maintenance, and soft costs. In addition, significant cost reductions can be achieved through lower-cost project capital. ${ }^{1}$

Project capital costs, or financing costs, are the costs associated with raising funds to build and operate a project. They typically come in two forms: the upfront costs associated with arranging funds (deal setup costs) and the costs required to pay back the sources of capital for providing project funds, plus profit ("the cost of capital" or "rate of return"). Key factors influencing financing costs include the amount of risk associated with achieving the investor's desired rate of return, the level of marketplace competition for available projects and sources of capital (i.e., the balance of supply and demand), ${ }^{2}$ and, to a lesser extent, the time and effort required to arrange a financial transaction.

Although research and development (R\&D) has already lowered PV financing costs, further reducing the perceived risk of cash flows to PV investors could reduce the cost of capital and increase the amount of leverage (i.e., the amount of debt as a percentage of total investment) in PV projects. We identify four R\&D areas that could enable lower capital costs and increase leverage through lower perceived risks and increased competition:

- Improving the durability, reliability, operations and maintenance, and testing of PV products (reducing technology risk)

- Improving capabilities for predicting solar resource and PV system production (reducing solar resource risk)

- Improving grid-integration technologies and practices (reducing risk of declining PV electricity value $)^{3}$

- Improving data transparency around system performance and payment history (reducing electricity off-taker risk)

Additional public and private activities such as analysis, data aggregation, and industry working groups and collaboration - which may involve some R\&D activities as well—could further reduce the cost of financing, often by enabling financing transactions to occur more quickly with less effort and reducing the upfront costs associated with arranging financing for PV projects. Compared with the cost of capital and the amount of leverage, these upfront costs have a smaller

\footnotetext{
${ }^{1}$ R\&D efforts also could lower supply-chain financing costs. In this report, we exclusively focus on project finance costs.

${ }^{2}$ Lower perceived risk of cash flows to PV investors also affects the amount of marketplace competition because it expands the number of investors willing to fund a project, increasing the supply of capital.

${ }^{3}$ Greater certainty in electricity value would reduce the risk of customer default or renegotiation as well as providing more confidence to investors in the price of electricity sales post-contract.
} 
effect on PV economics, but they could accelerate PV deployment. We identify an additional six areas of analysis that might lower financial transaction costs through business efficiencies:

- Streamlining processes and standardizing procedures and documentation for project development and due diligence

- Increasing the available customer base through market development

- Expanding new sources of capital ${ }^{4}$

- Enabling more efficient due-diligence and contingency planning via reduced project risk

- Improving technology (e.g., inverters, storage) and systems design for easier integration into the electrical grid

- Reducing operations and maintenance costs

To assess the impact these R\&D activities might have on PV financing costs, we estimate current, low-risk, and high-risk values for the risks associated with PV investment - that is, the volatility expected of equity returns, PV asset value, and debt payments for PV systems - as well as the upfront costs of arranging financial transactions. We input these estimates into financial models to analyze their impacts on the cost of capital for equity and debt investors, project leverage, and upfront financial transaction costs.

We find that current financing costs contributed approximately $36 \%$ to the LCOE of a utilityscale PV system built in 2017 (Figure ES-1). With other non-finance costs held constant, R\&Ddriven reductions in financing costs, from current levels to low-risk levels, could result in an $18 \%$ lower LCOE, reducing financing costs' LCOE contribution to approximately $21 \%$.

Alternatively, without the R\&D needed to prevent future risks and complications, financing costs may increase. We find that, if financial transactions become more difficult to arrange and market volatility rises owing to increased risk - such as widespread PV module failures or high gridintegration $\operatorname{costs}^{5}$ - the LCOE could rise by as much as $80 \%{ }^{6}$

\footnotetext{
${ }^{4}$ Expanding new sources of capital can also lower the cost of capital by creating more competition within the marketplace.

${ }^{5}$ For example, O'Sullivan and Warren (2016) found that Nevada's decision to roll back net metering for PV customers "likely increased the perceived risk of the underlying assets and thus may have impacted the risk/reward profile measured by the yield." Research related to the value of PV, and ways of sustaining that value, could reduce the number of changes to net metering programs or make those changes less punitive.

${ }^{6}$ We performed this analysis for the residential PV market as well and found similar results.
} 


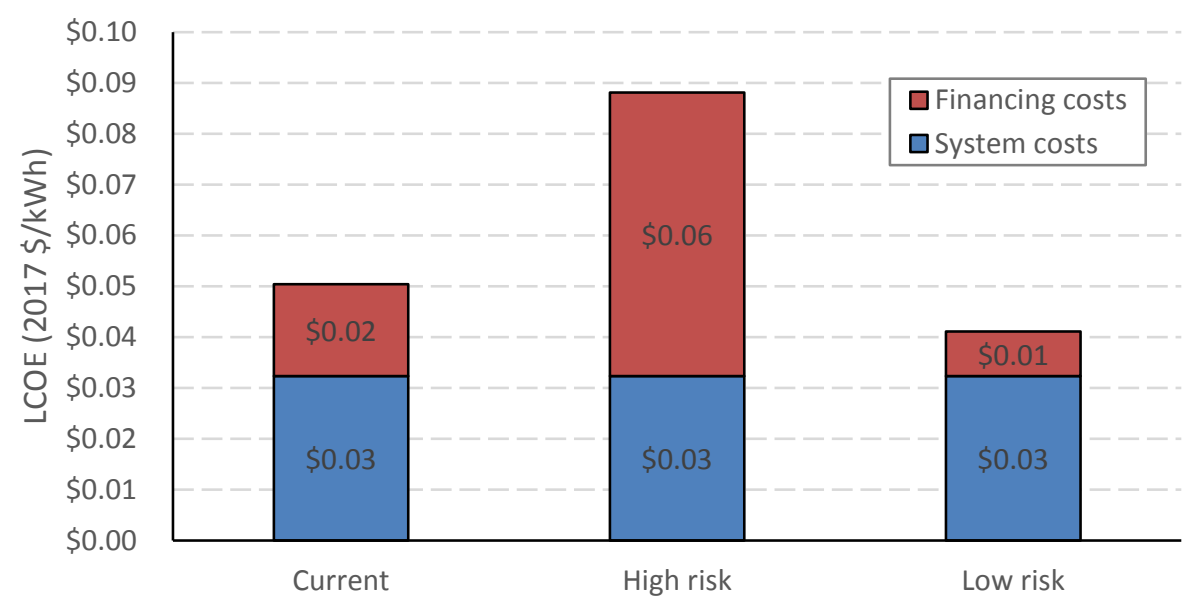

Figure ES-1. LCOE of a 2017 utility-scale PV system under current, high-risk, and low-risk financing scenarios 


\section{Table of Contents}

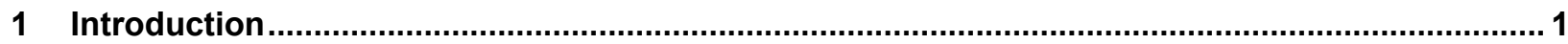

2 Impact of Historical PV R\&D, Analysis, and Standardization on the Cost of Financing.............. 3

3 Current and Future PV R\&D, Analysis, and Standardization Activities that May Impact

Financing Costs

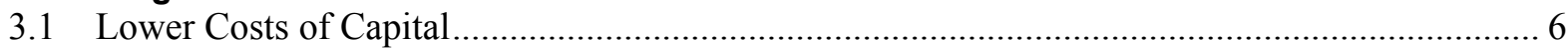

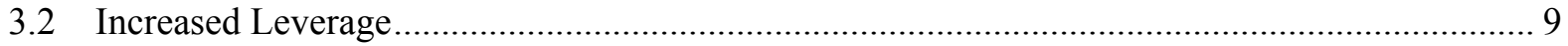

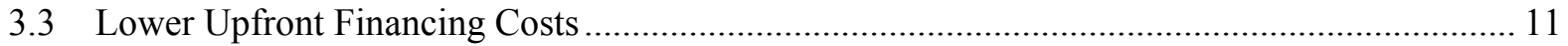

4 Methods for Quantifying the Impact of R\&D, Analysis, and Standardization Activities on

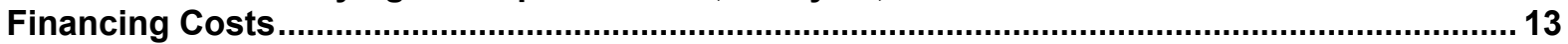

4.1 R\&D Effects on the Volatility/Risk of PV Asset Returns and Cash Flows ............................ 13

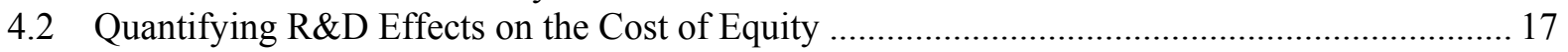

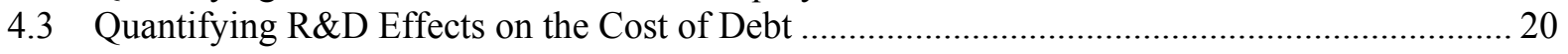

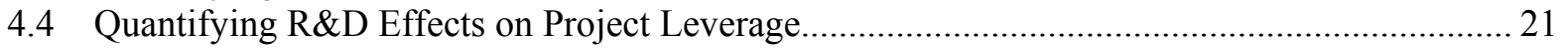

4.5 Quantifying Analysis and Standardization Effects on Upfront Costs .................................... 22

5 Results: R\&D, Analysis, and Standardization Impacts on Financing Costs and PV LCOE........ 23

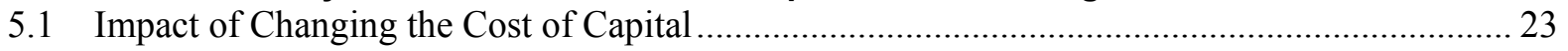

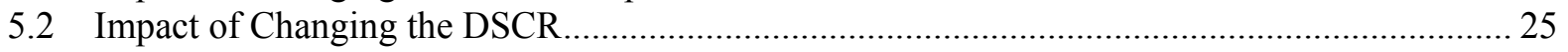

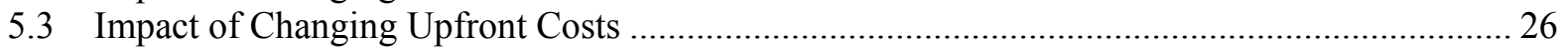

5.4 Summary of R\&D, Analysis, and Standardization Impacts on PV Financing Costs and LCOE 27

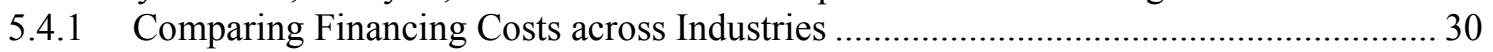

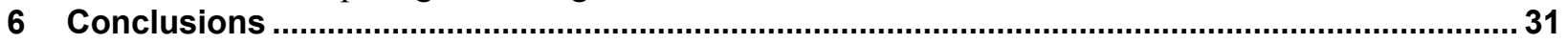

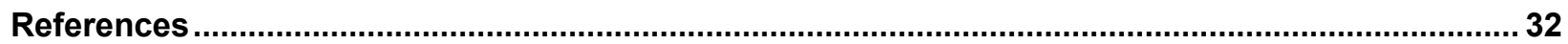




\section{List of Tables}

Table 1. Summary of Discussions with Independent Engineers and Financiers on the Impact of Recent PV R\&D, Analysis, and Standardization Activities on PV System Risks and Evaluation Processes

Table 2. R\&D Activities that Can Reduce PV Project Cash Flow Volatility Matched with Sources of

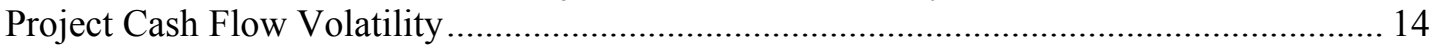

Table 3. Volatility of Equity Returns, Asset Value, and Debt Payments for PV Systems ....................... 17

Table 4. Upfront Costs Associated with Arranging Typical Financing ................................................. 22

Table 5. Assumptions Used in CAPM, PV Investment (values annualized unless otherwise stated) ........ 23

Table 6. Assumptions Used in the Merton Model, PV Investment ........................................................2 24

Table 7. Summary of R\&D, Analysis, and Standardization Impacts on PV Financing Cost .................... 28

Table 8. Summary of Financing Terms in the Current, Low-Risk, and High-Risk Scenarios, after

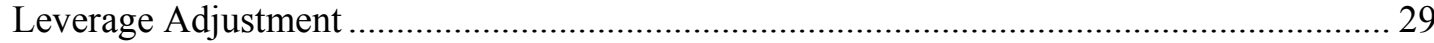

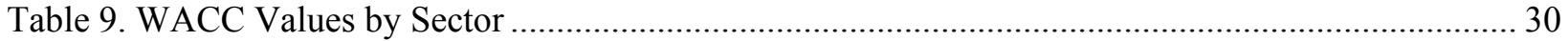

\section{List of Figures}

Figure 1. Changes in a utility-scale PV project's LCOE and IRR in year 20 based on system lifetime .... 19 Figure 2. LCOE of residential and utility-scale PV under the current, low-risk, and high-risk scenarios for the costs of equity and debt (variable equity and debt costs).....

Figure 3. LCOE of residential and utility-scale PV under the current, low-risk, and high-risk scenarios (variable DSCR).

Figure 4. LCOE of residential and utility-scale PV under the current, low-risk, and high-risk scenarios (variable upfront costs)

Figure 5. LCOE of residential and utility-scale PV under the current, low-risk, and high-risk scenarios (combined impacts from changes in equity and debt risk premiums, project leverage, and upfront financing costs, after leverage adjustment).....

\section{List of Equations}

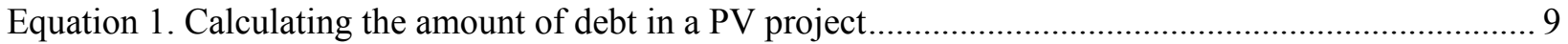

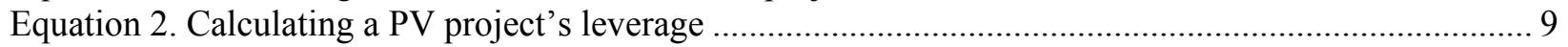

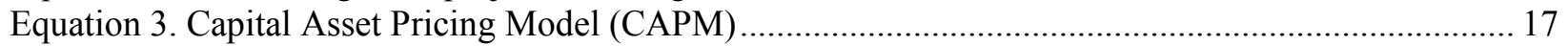

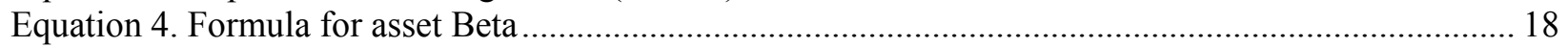

Equation 5. Adjusting the standard deviation of PV RoR by the change in standard deviation of electricity production (assuming it is uncorrelated to other volatilities in PV RoR) ............. 18

Equation 6. Formula for the credit spread on debt using the Merton Model ........................................... 21

Equation 7. Calculating P50 DSCR with P99 DSCR and standard deviation of debt payments ............... 22 


\section{Introduction}

Rapid declines in the cost of solar-electric generating systems have helped U.S. solar markets grow dramatically while spurring solar job growth (Solar Foundation 2017). In less than a decade, solar photovoltaic (PV) system installed prices have fallen by $60 \%$ or more across market segments (Fu et al. 2016, Bolinger and Seel 2016). These reductions can be attributed to improved technology performance, benefits from economies of scale, improved business practices (i.e., reduced "soft-costs"), and reduced financing costs. Nevertheless, further reductions in PV energy costs can enable significantly greater PV adoption and contribute to greater energy affordability. Recognizing this potential, the U.S. Department of Energy (DOE) recently set new targets for the levelized cost of electricity (LCOE) from PV; the targets to be achieved by 2030 without subsidies are $3 \phi / \mathrm{kWh}$ for utility-scale, $4 \notin / \mathrm{kWh}$ for commercial, and 5 $\phi / \mathrm{kWh}$ for residential systems (DOE 2016). Achieving these targets-which entails reducing costs by a factor of two to three from 2017 values - requires improved technology performance and reliability as well as lower hardware, operations and maintenance (O\&M), and soft costs. Within soft costs, significant cost reductions can be achieved through lower-cost sources of project capital, i.e., lower financing costs. ${ }^{7}$

Financing costs are the costs associated with raising funds to build and operate a project. They typically come in two forms: the upfront costs associated with arranging funds (deal setup costs) and the costs required to pay back the sources of capital for providing project funds, plus profit (the "cost of capital" or "rate of return"). Key factors influencing financing costs include the amount of risk associated with achieving the investor's desired rate of return, the level of marketplace competition for available projects and sources of capital (i.e., the balance of supply and demand), and, to a lesser extent, the time and effort required to arrange a financial transaction.

Research and development (R\&D) focused on improving technology and integrating PV with the electricity grid, and analysis and standardization focused on improving business practices can lower the cost of financing. Although PV projects will always entail investment risk and riskrelated costs, removing some of the perceived risk to investor cash flows - and thus increasing competition in the financial marketplace - could reduce the cost of capital and increase the amount of leverage (i.e., the amount of debt as a percentage of total investment) in PV projects. ${ }^{8}$ In addition, creating business efficiencies that allow financing transactions to occur more quickly with less effort could reduce the upfront costs associated with arranging financing for a PV project or group of projects. Various R\&D, analysis and standardization activities can contribute to these financial cost improvements.

This report quantifies the potential for $\mathrm{R} \& \mathrm{D}$, analysis and standardization activities to reduce the costs of financing PV projects and thus reduce PV's LCOE. Section 2 discusses historical R\&D, analysis and standardization that has reduced PV financing costs. Section 3 summarizes future R\&D, analysis and standardization activities that could drive PV financing costs down further.

\footnotetext{
${ }^{7} \mathrm{R} \& \mathrm{D}$ efforts also could reduce supply-chain financing costs. In this report, we focus exclusively on project finance costs.

${ }^{8}$ Because debt investors typically require a lower return on investment than do other sources of capital (i.e., equity) and the interest expense charged is tax deductible, increasing the amount of leverage typically lowers the weighted average cost of capital for a project. See Section 3.2 for more discussion on this topic.
} 
Section 4 details the methods we use to quantify the potential impact of R\&D, analysis and standardization activities on financing costs. Section 5 presents the results of our analysis in terms of potential R\&D-, analysis-, and standardization-driven reductions in financing costs and LCOE. Section 6 offers conclusions and directions for future work. 


\section{Impact of Historical PV R\&D, Analysis, and Standardization on the Cost of Financing}

Uncertainties can directly or indirectly impact a project's cost of capital. Investors in certain instances will offer a lower cost of capital for a less risky investment. However, in many cases investing is a binary decision for an institution: it chooses to invest or not invest. Previously the risks and uncertainties surrounding PV investments prevented many institutions from investing in PV. Because of the relatively few sources of funding and little competition to provide funds for PV system installations, PV financiers could seek a higher rate of return on their investments.

Through concerted effort and partnerships between public and private institutions, PV technology has become less risky over time and PV financial transactions more standardized. Improvements in product design and manufacturing have decreased module failure rates (Köntges et al. 2014, Strevel et al. 2014), lowered PV module degradation rates (Jordan and Kurtz 2012), reduced failure rates of power electronics within a PV system (Wang et al. 2014), and increased PV system lifetime (IEA-ETSAP and IRENA 2013), allowing PV module companies to offer longer warranties (Kuitche 2014) and creating more confidence in investors to make long-term investments. ${ }^{9}$

Because of the reduced uncertainties and associated risks, more banks have entered the PV project market. We spoke with financiers in the PV industry who said that research had led directly to more available funding. One financier stated that, 10 years ago, only five to 10 institutions provided financial instruments for PV projects, but now there are 30 . This proliferation of investors who are more comfortable with PV technology and financing arrangements has reduced the cost of capital for projects (CohnReznick 2017). For example, in 2010, the floating interest rate spread for PV projects was $3.5 \%$ above LIBOR ${ }^{10}$, and financing these projects required an additional 3.0\% upfront fee and a debt service coverage ratio (DSCR) $^{11}$ of 1.4 (Martin 2010, Chaudhry 2010). In 2017, the interest rate premium and upfront fee each fell to $1.5 \%-2.0 \%$, and the DSCR dropped to 1.3 (Martin 2017). Although the recovery of the financial sector after the 2008 economic crisis contributed to the lower PV project financing rates, the lower rates can also be attributed to improved investor confidence in the PV sector.

We spoke with nine independent engineers and PV project financiers, who said significant and expansive research performed over the past 10 years has contributed to less uncertainty, more efficient evaluation of PV projects, and lower financing costs. The research areas they mentioned include — but are not limited to — standardized qualifications test protocols, modeling, data

\footnotetext{
${ }^{9}$ Köntges et al. (2014) found that module failure rates for certification by the International Electrotechnical Commission (IEC) decreased from 54\% in 2002 to $10 \%$ in 2012. Jordan and Kurtz (2012) found a significant decrease in PV module degradation rates from pre-2000 to post-2000 installations. Kuitche (2014) found that PV module warranty length increased by 5 years every 6 years during 1987-1999.

${ }^{10}$ LIBOR, or the London Interbank Offered Rate, is a benchmark for the cost at which a bank can get a loan. The difference between the rate at which the bank gets the loan (i.e., LIBOR) and the interest rate the bank charges to a customer is known as the "spread" and represents the margin charged by the bank for making the loan.

${ }^{11}$ DSCR is the ratio of available cash flow (typically net operating income) to debt obligations (principal and interest payments) due within the same period. A higher DSCR indicates higher perceived risk.
} 
collection, and analysis. Table 1 summarizes some of the major recent R\&D activities mentioned in our discussions, along with the impact of the R\&D on PV system financing.

Table 1. Summary of Discussions with Independent Engineers and Financiers on the Impact of Recent PV R\&D, Analysis, and Standardization Activities on PV System Risks and Evaluation Processes

\begin{tabular}{ll}
\hline R\&D Activity & Result \\
\hline Sandia National Laboratories developed Open & Many independent engineers we spoke to stated \\
Source PV LIB, an open-source repository of PV & $\begin{array}{l}\text { that a better physical understanding of PV } \\
\text { analysis algorithms (Andrews et al. 2014). }\end{array}$ \\
& $\begin{array}{l}\text { generation has improved PV generation } \\
\text { estimates. }\end{array}$ \\
\hline
\end{tabular}

IEC committees, including the newly established IEC 61215 and IEC 61730, formalized (among other things) specific test sequences, conditions, and requirements for the design qualification of a PV module.

The National Renewable Energy Laboratory (NREL) created PV Qualification Plus test standards, a well-defined set of accelerated stress tests that correlate with the field performance of $\mathrm{PV}$ modules (Kurtz et al. 2013a).

The number of PV module tests increased to include accelerated lifetime testing, PotentialInduced Degradation (PID) and Light-Induced Degradation (LID) qualification, salt/mist testing, and testing the effects of exposure to ammonia and soiling (Meydbray and Dross 2017, Kurtz et al. 2013b).
The existence of widely accepted standards simplifies the analysis and qualification of $\mathrm{PV}$ projects and equipment, and it can improve performance estimates while reducing costs. For example, one independent engineer stated that before the development of soiling tests, performance degradation due to soiling in the western United States was assumed to be $7 \%$ $10 \%$ : due to research and analysis in this area he now uses a range of $3 \%-6 \%$. In addition, a few standardized test protocols have replaced the numerous protocols previously developed by individual organizations, and this has reduced the time for an independent engineer to evaluate the testing data. As a result, two interviewees stated that the cost of independent engineer reports on PV systems declined from $\$ 80,000$ in 2011 to $\$ 50,000-\$ 65,000$ in 2017 and the cost of independent resource and generation assessments declined from $\$ 15,000$ in 2011 to $\$ 5,000-\$ 6,000$ in 2017.

One interviewee stated that previously the PV industry used both the Hay model and the Perez transposition model, and the results from the two models differed by $2 \%-3 \%$. Standardized use of the Perez model reduces this uncertainty.
NREL provided extensive evidence for PV module and system annual performance degradation rates (Jordan and Kurtz 2012).
Interviewees stated that NREL's rigorous analysis helped impart confidence in PV module degradation values and, in some cases, demonstrated that degradation was slower than previously believed. In 2006 many in the PV industry assumed PV system degradation rates were approximately $1 \%$ per year. By 2017 , study results helped independent engineers reduce this assumption to $0.7 \%$ per year, and further analysis has enabled some independent engineers to be comfortable with $0.5 \%$ annual degradation for some projects. 
Updated Typical Meteorological Year (TMY) data

from the National Solar Radiation Data Base were published, providing more recent and accurate data on hourly values of solar radiation and meteorological elements (Habte et al. 2017).
The improved database has imparted more confidence in estimated PV system production.

Additional opportunities exist for R\&D, analysis and standardization to lower the perceived risks and thus financing costs associated with PV projects. Many investors still classify PV as an "exotic" asset class. Although 30 or more institutions are involved in PV financing, hundreds of banks are operating in more traditional asset classes like construction and home loans. The entrance of additional sources of funding, such as small and regional banks, into the PV project marketplace could drive down the cost of capital. Continued R\&D, analysis, and standardization are needed to reduce PV project uncertainties and risks enough to attract new investors. As the industry focuses on removing and reducing component costs, $R \& D$, analysis, and standardization will be particularly essential to assuring investors that quality remains high. 


\section{Current and Future PV R\&D, Analysis, and Standardization Activities that May Impact Financing Costs}

This section summarizes various current and future R\&D, analysis, and standardization activities that can drive down the cost of PV financing as well as the impact such improvements might have on PV's LCOE. We divide R\&D, analysis, and standardization activities and their impacts by the ways in which they improve financing: lower costs of capital, increased leverage, and lower upfront financing costs.

\subsection{Lower Costs of Capital}

Debt and equity investors fund PV project construction and operation to make returns on their investments. The return rate each investor desires - and thus the cost of capital - is impacted by a variety of factors. Supply and demand dynamics ${ }^{12}$ and the underlying interest rate the U.S. government charges banks play an important role in determining the required rate of return. In addition, the underlying risk of the cash flow a project receives and the risk of changes in perceived value of the asset play critical roles in determining investors' required rate of return, particularly in the long run. In general, investors require a higher rate of return to make investments that are perceived as riskier, and vice versa.

When financiers build financial models, they estimate their risk exposure by examining the sensitivity of returns to various risk factors. For example, financiers may look at expected project cash flows assuming an average level of production (or P50) and a production level that the project has a 99\% chance of exceeding (or P99). Narrowing the gap between the P50 and P99 scenarios lowers a project's overall perceived risk.

Risks affect different sources of capital differently. Equity investors own assets or a portion of assets. They enjoy the benefits of any appreciation in asset value, but they are also exposed to any reduction in asset value. Debt investors lend money that is paid back later, and they are compensated by interest payments; the debt investor has legal claim to any assets up to the amount borrowed, plus the interest, and that right supersedes that of the equity investor. However, debt investors typically have no claim on any "upside" due to asset appreciation while still being exposed to the "downside" of asset depreciation. Additionally, while equity investors do not necessarily need as much certainty about the cash flow they receive in a particular year as long as they earn profit on average, debt investors typically require set annual payments of interest and principal. If the project does not generate enough cash flow in any given year to pay the loan interest and principal, the loan is in default, and debt investors could be forced to recoup their investments through the value of the asset, or in some cases, the guarantor. A loan default can be costly for both sides, and if the asset's value has fluctuated downwards, the debt investor may not be able to recoup their original investment. Because of the need for certainty in cash flows and the lack of "upside" in the investment, debt investors are more exposed to cash flow and asset value volatility over the term of the loan.

\footnotetext{
12 That is, the total amount of money project developers need to build PV projects in relation to the total amount of investment dollars interested in investing - and able to invest - in PV projects.
} 
In any case, once the loan is paid back at the end of the term, debt investors no longer have a stake in the project. Similarly, tax-equity investors receive most of their benefits from tax credits, or offsets, and their percentage of ownership declines once those credits are used, typically after the first 5 to 10 years of a project. Therefore, debt and tax-equity investors are less exposed to long-term risk than are long-term equity investors.

R\&D efforts can reduce different types of risks to cash flows. We discuss four specific R\&D opportunities below.

Reducing technology risk by improving the durability, reliability, O\&M, and testing of PV products. PV technology R\&D — which can include basic science, improved modeling and testing capabilities, and material, component, and system design and experimental work - can impact financing costs by lowering the perceived investment risk. ${ }^{13}$ R\&D efforts that improve PV durability, reliability, O\&M, and testing reduce the uncertainty of energy production over the lifetime of PV systems. Consequently, financiers can become more confident that a PV project will generate its expected level of electricity over the life of the asset, without the need for additional costs for repair or replacement. There is also a degree of uncertainty in electricity production caused by module soiling, which can be mitigated through improved O\&M practices and advanced materials science. Reducing the volatility of energy production and O\&M expenses during the term of the debt will create more certainty that project owners can service their loans, as well as receive funds themselves. Further, if investors believe there is significant value post-contract - for example, because generation will continue for another 15 years after a power-purchase agreement (PPA) expires - then the long-term equity investor's required return during the contract period likely will be lower.

Reducing solar-resource risk through improved production forecasting. Improved coupling of weather forecasting to PV system generation can improve predictions of solar electricity production over various timescales (seconds, minutes, hours, days, years), which reduces the uncertainty in energy revenue projections by creating more certainty about the value and resiliency that a PV system provides to the electricity system. Improvements in short-term solar performance forecasting can also increase a PV project's capacity value (Sigrin et al. 2014). This could enable projects to bid into capacity markets (where available), or it could increase the price of a PPA by bundling capacity value into the price, creating more certainty in project cash flow.

Reducing electricity value risk through improved grid integration. The value of solar energy can decline as the proportion of an electricity system's total generation contributed by solar increases (Denholm et al. 2016, Barbose et al. 2016, Mills and Wiser 2012). However, gridintegration R\&D - resulting in advanced inverter designs that allow PV systems to supply grid services, improved communications, better integration with energy storage and demand response, and so forth - can mitigate the risk of lost solar value while enabling a broader set of revenue streams for PV systems. ${ }^{14}$ These R\&D efforts will particularly benefit investors when they assess the post-contract value of a PV project. If investors believe, for example, that PV

\footnotetext{
${ }^{13}$ PV product improvements, such as lower manufacturing costs or improved system output (e.g., greater module efficiency) are more likely to have a direct effect on PV system electricity costs rather than financing costs. This topic is discussed in detail at the end of Section 3.2.

${ }^{14}$ Other revenue streams include capacity value and ancillary services, such as operating reserves and voltage control (including provision of reactive power) (Denholm et al. 2014).
} 
electricity will be sold at a reasonable price after PPA expiration because the value of this electricity has not declined precipitously with increased PV deployment, then their required return during the contract is likely to be lowered. In other words, the higher the assumed residual value, the more likely an investor will be willing to take a lower rate of return during the contract period. Although most PV projects currently have long-term energy contracts, and thus are not exposed to fluctuations in the underlying electricity value over the period of the contract, some recent U.S. and international projects have structured their transactions with shorter-term PPAs (Roselund and Lopez 2017a), or with some amount of merchant power sales (Roselund and Lopez 2017b, Bellini 2017). This trend may continue, because most other energy generation facilities sell their power in this way; if it does, reducing electricity value risk will become even more important. In addition, with more certainty in electricity value, there will be less risk in customer creditworthiness because there is potential for the electricity to be sold to another party.

\section{Reducing electricity off-taker risk and energy production risk by improving data transparency related to system performance and payment history. To reduce the risk of} electricity off-takers not paying their bills, PV financiers historically have relied on traditional methods of assessing credit, such as a FICO score for residential customers. However, because $\mathrm{PV}$ is a relatively new asset class, these traditional methods may not properly judge the risk of nonpayment. In addition, because most PV systems have been installed in the past few yearsand are often owned and operated by private companies - data on PV system performance are limited, particularly data on energy production over short intervals. R\&D focused on compiling and analyzing system performance and payment history - and communicating these findings to the financial community - can increase the certainty of cash flows and reduce the risk of customer creditworthiness.

In addition to these areas of $\mathrm{R} \& \mathrm{D}$, other forms of public and private efforts can lower the cost of financing, such as the following:

Lowering rates by expanding new sources of capital. Because the cost of capital depends on the supply of capital, initiatives focused on bringing new sources of capital into the market, including more tax-equity investors, could lower the weighted-average cost of capital (WACC ${ }^{15}$ ) for PV projects. For example, Feldman and Bolinger (2016) found that the emergence of new sources of capital—such as public markets (e.g., asset-backed securities [ABS], YieldCos ${ }^{16}$ ), solar-specific loans, and online financing platforms - reduced PV LCOE by $10 \%-20 \%$. These products became possible through joint public and private efforts to open these markets through working groups, technical reports, and public and regulatory outreach, such as the NREL-led Solar Access to Public Capital (SAPC) working group funded by DOE's Solar Energy Technologies Office.

\footnotetext{
${ }^{15}$ WACC represents the average rate of return an entity expects to return to its investors, with each source proportionately weighted by its required rate of return. The rate of return for debt investors is also typically multiplied by 1 minus the tax rate to account for the value of interest rate deductions for a company.

${ }^{16}$ A YieldCo is a publicly traded company that owns a portfolio of operating projects and distributes a large proportion of net revenue to shareholders in the form of regular cash dividends (which provide the shareholders' "yield"). Renewable generation projects are common holdings for YieldCos.
} 


\subsection{Increased Leverage}

The WACC is determined not only by the rates of different sources of capital, but also by the percentage each source contributes to project funding. Because the claims of debt investors on project cash flow typically supersede those of equity investors, debt investors typically perceive less risk of not receiving their return and thus require a lower return compared with equity investors. Therefore, the more debt a project has as a percentage of its total investments - that is, the more the project is leveraged - the lower the project's WACC. Multiple variables determine a project's leverage, including energy production, energy value, O\&M costs, the cost of debt (interest and principal payments), system price, and DSCR (Equation 1 and Equation 2). For example, all else being equal, a lower interest rate gives a PV project the ability to raise more debt, thus providing higher leverage.

\section{Equation 1. Calculating the amount of debt in a PV project ${ }^{17}$}

$$
\text { Amount of Debt }=\frac{\text { Energy Production } \times \text { Energy Value }-O \& M \text { costs }}{D S C R \times \text { Interest Rate }}-\frac{\text { Principal Payments }}{\text { Interest Rate }}
$$

\section{Equation 2. Calculating a PV project's leverage}

$$
\text { Leverage }=\frac{\text { Debt }}{\text { System Price }}
$$

The R\&D efforts described in Section 3.1 could affect all the variables that determine leverage, but the amount by which changing a variable increases debt depends on changes in the other variables. In a competitive marketplace, an owner seeking to win a contract likely will offset an improvement, such as a reduced system price (which would reduce the amount of debt, assuming a constant leverage), with a lower electricity sales price (which would reduce electricity revenue). Therefore, although these variables can impact leverage, it is typically more useful to measure their impact in terms of lower energy prices (e.g., LCOE).

The exception to this rule is the DSCR, because reducing the DSCR always increases the amount of debt in relation to the cash flow. The DSCR protects investors against perceived cash flow risks. With more certainty to project cash flows, lenders likely will be more willing to lower the DSCR. For example, reducing the minimum DSCR at P50 from 1.4 to 1.3 means that a lender would be willing to increase its lending from $\$ 1.00$ for every $\$ 1.40$ of expected cash flow to $\$ 1.07$. In addition, with lower risks, PV projects more likely would satisfy stress-risk scenarios in financial models; in other words, R\&D efforts to reduce risk can increase expected cash flows in the worst-risk scenarios (e.g., lower than expected electricity production) and thus enable higher leverage.

\footnotetext{
${ }^{17}$ The debt calculation is derived from the following three formulas (interest only loans would not have principal payments):

1) Debt Payments $=$ Amount of Debt $\times$ Interest Rate + Principal Payments

2) Operating Cash Flow $=$ Electricity Revenue - O\&M

3) $D S C R=\frac{\text { operating Cash Flow }}{\text { Debt Payments }}$
} 


\section{Other R\&D Efforts that May Impact Leverage}

As discussed at the beginning of Section 3.2, several variables can influence the leverage of a PV system but are more likely to affect the cost of energy. Some of these are noted below.

Higher expected energy production. Debt providers determine the amount of money they are willing to lend to a project by ensuring future cash flows can cover the debt payments on the loan (i.e., the "debt service"). Debt providers typically perform financial calculations to determine whether the DSCR for a project is met under a variety of scenarios. For example, a lender may require that a project have a minimum DSCR of 1.0 under P99 production levels, and a minimum DSCR of 1.4 under P50 production levels. The higher the expected energy production under both the P50 and P99 scenarios, the more debt a project can borrow. Therefore, the expected production and confidence in that projection (represented by the difference between the P50 and P99 scenarios) can play an important role in the amount of leverage on a project.

Various R\&D activities relate to increasing PV system energy production, including R\&D to improve degradation rates and lifetime, new coating materials and module designs that have less reflectivity and better performance in low-light conditions, more reliable and efficient inverters, and new tools and analysis techniques that improve O\&M effectiveness. In addition, the expected production of a system may increase through improved solar resource and generation forecasting as well as better predictive module testing capabilities. Many of these $\mathrm{R} \& \mathrm{D}$ activities are particularly relevant in relation to the $\mathrm{P} 99$ production level, because greater knowledge and less chance of failure could narrow the gap between the extreme and average cases.

Lower system price. R\&D continues to reduce the price of PV hardware and to reduce soft costs. If a PV system costs less but produces energy with the same value, the dollar amount of the project debt could remain the same, resulting in higher leverage. That said, system price reductions often translate into lower electricity sales prices (e.g., lower PPA prices). In those instances, project cash flows would decline in proportion to the system price, and the leverage would remain the same.

Greater expected electricity value. Although solar energy production is important, an investor's primary concern is cash flow. Increasing production can increase cash flows, but increasing the value of each unit of solar energy through $R \& D$ can also contribute. The risk of lower solar electricity values at higher PV penetrations can be reduced through improved solar generation forecasting, advanced inverter designs, improved communications, and better integrated technology and system designs. For example, R\&D to advance inverter capabilities can enable PV assets to generate a broader set of revenue streams through ancillary services. If investors believe solar electricity has more value, they are more inclined to assume higher project cash flows; holding the DSCR constant, higher cash flows allow a higher amount of project leverage. Currently, most PV asset revenue is exclusively tied to cash flow from PPAs, and therefore increasing leverage through greater expected electricity value would only occur to the extent that the expected value of the electricity post-contract allows for an increase in leverage. 


\subsection{Lower Upfront Financing Costs}

Structuring financing for a PV asset often involves arranging, negotiating, and contracting agreements between two or more parties. These activities can cost millions of dollars, including various legal, accounting, engineering, and financing costs as well as the time-related costs of a longer development and construction timeline. Research, analysis, and process standardization could lower these costs and reduce the timeline to financial closing. This work will require collaborative efforts between many entities, both public and private. We look at five areas of work that might influence upfront financing costs.

Streamlining processes, standardizing procedures and documentation. Recreating financial documents for every new transaction can be extremely costly and time consuming. A lack of standardization can also create risk for financial participants because of the added uncertainty and lack of transparency due to using new or different documents, procedures, or technologies. Leadership efforts involving PV industry participants, such as the SAPC working group, have been streamlining financing transactions through standardized approaches and contracts. Standardization makes documents and entire projects more transparent and accessible, thus reducing risk, time, and cost. For example, through the SAPC working group, various industry members worked together to produce a standardized PPA for residential and commercial PV systems, a standardized lease agreement for residential systems,${ }^{18}$ and a best-practices guide for PV installations (Doyle et al. 2015). Still, there is further opportunity for standardization practices to lower upfront financing costs. A standardized suite of qualification and reliability tests for modules and systems, which have been evaluated by a third party for their relevance, could reduce duplicative testing procedures for all parties. This would reduce time and redundancies and likely also lower perceived risks. Although NREL has performed some of this work already, such as creating the Qualification Plus standards (Kurtz et al. 2013a), there is still room for further work to provide better predictive tests.

Increasing the available customer base. Every financial transaction has fixed costs; the larger the transaction, the less impact these costs have on project economics. In addition, investors in $\mathrm{PV}$ system transactions will typically only participate if the transaction is at least a minimum size, from $\$ 25-\$ 100$ million. ${ }^{19}$ One way to increase the size of financial transactions and minimize the time required to reach a minimum transaction size is to bundle more PV systems together into one financial transaction; this would be easier to achieve with an increase in the available customer base of solar electricity off-takers (including commercial and government entities). In 2016, the United States installed its millionth residential PV system, but many of the country's more than 116 million households have no access to PV or PV financing solutions. Efforts to expand market participation include work on shared solar project models, which could open up the PV market to $49 \%$ of U.S. households and $48 \%$ of U.S. businesses that are currently unable to host a PV system (Feldman et al. 2015). Another effort is the expansion of PV to lowand moderate-income families through DOE's National Community Solar Partnership. ${ }^{20}$

\footnotetext{
${ }^{18}$ See the SAPC website at https://financere.nrel.gov/finance/content/solar-securitization-and-solar-access-publiccapital-sapc-working-group.

${ }_{19}$ A single utility-scale PV project can meet these minimums, as can a portfolio of residential PV systems.

${ }^{20}$ For information about the National Community Solar Partnership, see

https:/energy.gov/eere/solarpoweringamerica/national-community-solar-partnership.
} 
Reducing project risk. Financial transactions are time consuming and expensive, requiring extensive legal, engineering, technology, and environmental due-diligence analysis. Due diligence represents a large, necessary cost to ensure that all parties are aware of the risks associated with their investment. Various R\&D activities can lower a project's cash flow risk (see Section 3.1). With fewer risks and more information about these risks available to investors, the upfront costs of due diligence and the time associated with performing a financial transaction may decrease.

\section{Improving technology and system design for easier integration into the electrical grid.} Interconnecting a PV asset to the electrical grid requires regulatory approval. As U.S. PV deployment has increased, the interconnection process has become more complicated in certain areas because of the impact PV may have on grid operation. A better understanding by all participants of how to integrate PV into the grid and how PV can contribute to power quality and grid reliability could lower the upfront time and cost of closing a project finance transaction by reducing due-diligence costs as well as reducing interest payments and fees associated with the construction loans required for the interconnection-approval period.

Reducing O\&M costs. Project owners typically set aside an upfront cash reserve to pay for O\&M incurred over the life of the system. Lower assumed O\&M costs result in a lower required reserve value, less upfront cash outflow, and more cash going to the owner over the life of the project. $R \& D$ that can enable lower O\&M costs - such as improvements to module and inverter lifetimes and better characterization and analytical tools - could result in lower financial transaction costs by reducing the cash reserve. 


\section{Methods for Quantifying the Impact of R\&D, Analysis, and Standardization Activities on Financing Costs}

This section describes our methods for quantifying how R\&D, analysis and standardization could influence the costs of equity and debt, the amount of leverage, and the upfront costs for PV projects. The analysis centers on how the anticipated volatility of PV project financial metrics translates into perceived investor risk and shapes the financial terms available to a project. We estimate the current volatility/risk of PV asset values, returns, and cash flows as well as possible lower and upper bounds for these metrics should the R\&D efforts outlined in Section 3 succeed or fail. We then discuss our methods for analyzing how R\&D-driven changes to these calculated volatilities/risks could affect financing terms, and how analysis and standardization could affect upfront financing costs.

The two primary models we use to estimate the impact of risk on the cost of capital are the Capital Asset Pricing Model (CAPM), for equity, and the Merton Model, for the debt risk premium. Although these models are widely used to calculate the cost of capital, a significant body of literature identifies their limitations. The models do not necessarily take into account realties within the marketplace, such as irrational actors (Dempsey 2013, Shiller 2003) and sector-specific differences in behavior, such as with small companies (Bantz 1981) or companies with higher earnings yields (Basu 1977). In addition, although they are static models (calculating a specific moment in time), they are often used in a dynamic marketplace (Merton 1973). With these, and other (Kürschner 2008), limitations in mind, we feel these models are particularly well suited for long-term risk assessment (e.g., see Mullins 1982).

\subsection{R\&D Effects on the Volatility/Risk of PV Asset Returns and Cash Flows}

The vast majority of financial transactions involving PV assets are private, and it is difficult to know the volatility of their returns. Therefore, we generate a bottom-up estimate of PV asset return volatility using standard deviation as a proxy for volatility. ${ }^{21}$ First, we match the R\&D categories summarized in Section 3.1 with three distinct sources of cash flow volatility for a PV project (Table 2). We then estimate current, "high risk," and "low risk" scenarios for each source of volatility.

\footnotetext{
${ }^{21}$ Further research on this topic would provide tremendous value for assessing the volatility in value of PV systems.
} 
Table 2. R\&D Activities that Can Reduce PV Project Cash Flow Volatility Matched with Sources of Project Cash Flow Volatility

\begin{tabular}{|c|c|}
\hline $\begin{array}{l}\text { R\&D activities that can reduce PV project } \\
\text { cash flow volatility }\end{array}$ & Sources of project cash flow volatility \\
\hline $\begin{array}{l}\text { Reducing technology risk by improving } \\
\text { the durability, reliability, O\&M, and testing } \\
\text { of PV products }\end{array}$ & - $\quad$ PV system electricity production \\
\hline \multicolumn{2}{|l|}{$\begin{array}{l}\text { Reducing solar-resource risk through } \\
\text { improved production forecasting }\end{array}$} \\
\hline \multirow{3}{*}{$\begin{array}{l}\text { Reducing electricity value risk through } \\
\text { improved grid integration }\end{array}$} & - Regulatory uncertainty \\
\hline & $\begin{array}{l}\text { - Value of competing electricity (e.g., fuel costs, } \\
\text { retail rates) }\end{array}$ \\
\hline & - Customer credit \\
\hline $\begin{array}{l}\text { Reducing electricity off-taker risk and } \\
\text { energy production risk by improving data } \\
\text { transparency related to system } \\
\text { performance and payment history }\end{array}$ & $\begin{array}{l}\text { - } \text { Customer credit } \\
\text { - PV system electric production }\end{array}$ \\
\hline
\end{tabular}

Volatility from PV system electricity production. Using three data sets of historical production data and independent engineering reports from two separate ABS transactions, Kroll Bond Rating Agency (KBRA) estimated the standard deviations of electricity production for distributed PV assets to be $8.9 \%, 10.6 \%$, and 10.7\% (KBRA 2015a, KBRA 2015b). We use the median standard deviation of $10.6 \%$ to estimate PV production volatility, with the caveat that although this standard deviation is based on data from thousands of distributed PV systems-it does not necessarily reflect the standard deviation for PV systems in all locations and market sectors (e.g., the utility-scale sector).

Electricity production volatility can be divided into three separate sources: resource availability, technology risk, and O\&M. Ryberg et al. (2015) calculated a 3.3\% variation in resource availability (or U.S. average inter-annual production), indicating that O\&M and technology risk contribute significantly to the estimated $10.6 \%$ standard deviation of production volatility. That said, because most PV systems in the data sets we use for our estimate are relatively new, they may not fully capture the volatility in returns caused by technology risk and O\&M over the full life of a PV system.

Volatility from customer credit. To estimate customer credit risk, we examined PPA and lease contract reassignment data from a third ABS transaction (KBRA 2015c). In cases of reassignment, the system owner attempts to recover the value of the contract by reassigning it to a third party. While most contracts are transferred to the new homeowner, other reassignments typically results from customer financial distress (KBRA 2015c). Based on the data examined, the owner successfully recovered $98.8 \%$ of the value of the contracts reassigned. Although reassignments represent a relatively small portion of total contracts, most contracts are relatively new, and the percentage may rise as average contract age increases. Additionally, given that $5.5 \%$ of U.S. homeowners moved in 2017 (implying that homeowners move every 18 years, on average) a contract reassignment is likely to occur for a residential (and likely a commercial) PV system over the course of its life (U.S. Census Bureau 2017). To be conservative, we assume the 
98.8\% recovery rate applies to all customer contracts, reasoning that, on average, U.S. homeowners will move before the end of a 20-year PPA. ${ }^{22}$ Assuming the median recovery value of a contract is $98.8 \%$, and approximately four standard deviations above the mean is a $100 \%$ recovery value (assuming that recovery value follows a normal probability distribution), then the four standard deviations total $1.2 \%$ (100\% minus $98.8 \%$ - and one standard deviation is $0.3 \%$. This value does not necessarily reflect the credit score for all pools of customers, locations, or market sectors.

Volatility from regulatory uncertainty. Regulatory uncertainty risk - the risk that a regulatory change could change the economics of existing PV systems - is an important consideration deserving of further research. To date, virtually all U.S. PV systems have avoided such changes, even if future systems in those areas do not receive the same treatment. For example, Nevada regulators changed the state's net metering policy in 2016 for new and existing PV systems, lowering the value of PV systems for people who had already made investment decisions. But public outcry spurred the regulators to change the rules again so they grandfathered existing systems into the previous net metering program for the next 20 years. In addition, electricity from most PV systems is sold under PPAs, so these systems are not exposed to regulatory uncertainty during the length of their electricity contracts. That said, regulatory change at the federal, state, or local level could occur in the future, which would affect PPA customers and PV system owners not under a PPA, potentially resulting in a loss of contract value separate from customer credit (such as contract renegotiation apart from or during contract reassignment). Additionally, regulatory changes affecting the value of PV electricity may impact a customer's willingness to pay system owners. Because we have no data on such regulatory change, for this analysis we simply assume a one standard deviation probability (i.e., a $68 \%$ probability) that one state (2\% of states) will make a regulatory change over the life of an asset that takes away or significantly reduces the benefits being received by existing PV systems. ${ }^{23}$

Volatility from value of competing electricity. A PV system can hedge against changes in future electricity costs because the dominant share of its lifetime costs is paid up front rather than in the future. The actual hedging value is related to the cost of electricity from competing sources (i.e., the cost of electricity that PV is hedging against). Reducing the cost of competing electricity reduces the value of the PV system, increasing the probability of customer default. Although stronger customer credit reduces the probability of default, we consider the risk associated with lower competing electricity cost to be independent of customer financial distress. From 1990-2015, the average residential retail electricity rate in the United States had a relative standard deviation of $17 \%$, but individual state averages had a range of volatilities (i.e., relative standard deviations) from $9 \%$ to $43 \%$ (EIA 2016). The value of competing electricity is in many

\footnotetext{
${ }^{22}$ Fifteen-year PPAs are also common within the industry, although many financiers assume that customers will opt for a 5- to 10-year contract extension. In addition, most U.S. PV systems were installed after the 2008 mortgage crisis; should another economic crisis affect U.S. housing sales, this could impact contract reassignment value. Although PV R\&D would have a very small effect on any economic crisis, some R\&D activities could retain or increase the value of PV-generated electricity, which would lower the risk related to individual customer credit. These factors would also vary greatly for the utility-scale PV market.

${ }^{23}$ Although PV benefits have been reduced in many states, including reductions to the credit customers receive for exported energy through net metering programs, these changes have primarily affected PV systems built after the adjustments, because existing systems have been grandfathered into the previous programs. These changes do not represent regulatory uncertainty for a PV project investment, because the benefits received from previous investments are protected. However, they would represent regulatory uncertainty for investment in a PV company.
} 
ways independent of PV R\&D, so this uncertainty will always persist (e.g., PV R\&D has no effect on the cost of natural gas). However, PV R\&D can spur higher PV deployment and functionality, which could create more certainty in future electricity prices owing to lack of fuel risk, fewer required distribution upgrades, and PV being in competition more with itself (i.e., instead of distributed PV systems competing against retail rates, they would compete against other PV systems). PV system owners with PPAs or leases are only exposed to this risk during the term of the contract to the extent that this effects counterparty default risk, although presumably the volatility in electricity costs is an important factor in determining the residual value of a PV system (i.e., its value after the contract).

Volatility from all sources under analysis scenarios. Assuming the four sources of volatility are not related, their variances (standard deviations squared) can be summed, and the standard deviation (i.e., volatility) of the four sources of volatility can be derived by taking the square root of the total. Excluding the volatility of competing electricity gives a combined PV asset volatility of approximately $10 \%$. Including the volatility of competing electricity (using the average residential retail rate volatility), gives a volatility of approximately $20 \%$. Because of the effect that competing electricity has on the residual value of a PV system and on counterparty default risk (independent of customer credit), we assume current $P V$ equity returns and $P V$ asset value have a volatility of $20 \%$.

DSCR is used to mitigate the risk of underperformance in payment over the term of the loan (which is almost always structured to be shorter than the term of an electricity contract), so it does not incorporate all potential risks over the lifetime of an asset, such as residual value. For this reason, we do not incorporate the volatility of competing electricity and assume a current volatility of $10 \%$ for debt payments when calculating DSCR, which matches DSCR values reported in Martin (2017). ${ }^{24}$

To assess the impact of PV R\&D, we examine how a change in volatility affects the cost of equity and debt as well as DSCR under "low-risk" and "high-risk" scenarios. In the low-risk scenario, for equity returns and asset value (used to measure debt value), we assume technology and O\&M volatilities are removed, leaving only fluctuations in resource availability (3.3\%). We also assume the volatility of competing electricity is reduced to the low end of the range for individual residential retail rate state averages $(9 \%)$, because PV R\&D can only have limited impact on competing electricity prices. Under these assumptions, the volatility of equity returns and PV asset value declines from $20 \%$ to $10 \%$. For DSCR, we assume all volatility in debt payments is removed except for volatility due to resource availability, which reduces volatility from $10 \%$ to $3.3 \%$.

In the high-risk scenario, for equity returns and asset value, we assume technology risk and O\&M increase electricity production volatility from $10.6 \%$ to $20 \%$, customer credit and regulatory volatility increase to approximately $5 \%$, and competing electricity volatility increases to the upper end of the range for individual residential retail rate state averages $(43 \%)$. Under

${ }^{24}$ For a PV system, the DSCR for P99 is typically 1.0, and currently the DSCR for P50 (i.e., the mean) is 1.3 (Martin 2017). These two DSCRs imply a standard deviation in cash flows of around $10 \%$ based on the following equation:

$$
\text { Standard Deviation }=\frac{D S C R_{P 50}-D S C R_{P 99}}{D S C R_{P 50} \times Z \text { score }_{P 99}}
$$


these assumptions, the volatility of equity returns and PV asset value increase from approximately $20 \%$ to approximately $45 \%$. For DSCR, we use these same high-risk scenario assumptions but still exclude competing electricity volatility, which increases debt payment volatility from approximately $10 \%$ to approximately $20 \%$. The volatilities of our current, lowrisk, and high-risk scenarios are summarized in Table 3.

Table 3. Volatility of Equity Returns, Asset Value, and Debt Payments for PV Systems

\begin{tabular}{lccc}
\hline & \multicolumn{3}{c}{ Volatility by Scenario } \\
& Current & Low Risk & High Risk \\
\hline Equity returns & $20 \%$ & $10 \%$ & $45 \%$ \\
Asset value & $20 \%$ & $10 \%$ & $45 \%$ \\
Debt payments (for DSCR) & $10 \%$ & $3.3 \%$ & $20 \%$ \\
\hline
\end{tabular}

The assumed volatilities summarized in Table 3 are based on limited data, many of which come from third-party-ownership distributed PV transactions in particular U.S. regions. It is likely that different market segments (e.g., host-owned residential PV, utility-owned PV) have different volatility ranges, and therefore the risks of each market segment should either be calculated separately or this uncertainty in differences adds to the other uncertainties in assumptions that we note above. That said, we use the volatility scenarios in Table 3 to measure the impact that changes in the volatility of PV returns, asset value, and debt payments have on financing cost, and then we use these calculations to estimate the impact that PV R\&D initiatives have on financing cost.

\subsection{Quantifying R\&D Effects on the Cost of Equity}

We use CAPM to measure the impact that changes in the volatility of equity returns, as calculated in Section 4.1, have on the cost of financing. CAPM is a valuation model that estimates the expected return of an investment by adding the expected return of a risk-free investment (to account for the time-value of money) to the premium charged by investors owing to the riskiness of the investment. The model assumes this investment is added to a welldiversified portfolio, so the risk of the individual stock depends on whether it is more or less volatile than the market as a whole and whether its returns fluctuate with the market or in opposition to it. Equation 3 summarizes the formula for CAPM.

\section{Equation 3. Capital Asset Pricing Model (CAPM)}

$$
R_{A}=R_{F}+B_{A L} \times\left(R_{M}-R_{F}\right)
$$

$\mathrm{R}_{\mathrm{A}}=$ expected return on an investment

$\mathrm{R}_{\mathrm{F}}=$ expected return on a risk-free investment (e.g., U.S. Treasury bond)

$\mathrm{B}_{\mathrm{AL}}=$ levered "Beta," or the measure of systematic risk of an investment compared with the overall market, adjusted for the amount of debt in an investment

$\mathrm{R}_{\mathrm{M}}=$ expected return from the overall market (e.g., based on the S\&P 500 index)

Using CAPM, the volatility (i.e., standard deviation) of an investment's cash flow changes the return on a project by changing its Beta $\left(\mathrm{B}_{\mathrm{AL}}\right)$. The formula for Beta is as follows: 


\section{Equation 4. Formula for asset Beta}

$$
\text { Beta }=\text { Correlation Coefficient }\left(R_{A}, R_{M}\right) \times \frac{\text { Standard Deviation }\left(R_{A}\right)}{\text { Standard Deviation }\left(R_{M}\right)}
$$

Reducing the standard deviation of an investment $\left(\mathrm{R}_{\mathrm{A}}\right)$ in isolation reduces the Beta which would reduce the expected return of an investment. However, any change in the volatility of the return could also affect the degree to which the return correlates with the return of the market as a whole $\left(\mathrm{R}_{\mathrm{M}}\right)$; this correlation is represented in the formula by the "correlation coefficient." 25,26 Therefore, determining the impact R\&D, analysis, and standardization efforts have on the cost of capital requires determining both the impact to risk (i.e., volatility) and to correlation. At present, many of the qualities of a PV asset are more likely to reduce correlation (e.g., low operating expenses, no fuel risk). If we assume no change in correlation, we can calculate the effect of R\&D efforts by analyzing only the change in the volatility of the return. Assuming that the impact an R\&D effort has on a particular aspect of PV's volatility in rate of return, such as electricity production, is uncorrelated to other factors affecting the volatility of PV's rate of return (such as customer credit, or other variations in system production), then we can adjust the standard deviation of PV's rate of return as shown in Equation 5.

\section{Equation 5. Adjusting the standard deviation of PV RoR by the change in standard deviation of electricity production (assuming it is uncorrelated to other volatilities in PV RoR)}

New St.Dev. of PV RoR = $\sqrt{(\text { Previous St.Dev.of PV RoR })^{2}-\text { Change in Variance of Electricity Production }}$

The adjusted standard deviation can then be input into Equation 4, and we can use this new Beta to calculate a revised cost of equity.

\footnotetext{
${ }^{25}$ Correlation Coefficient $=\frac{\text { Covariance }\left(R_{A}, R_{M}\right)}{\text { Standard Deviation }\left(R_{M}\right) \times \text { Standard Deviation }\left(R_{A}\right)}$

${ }^{26}$ Values for a correlation coefficient range between -1 (signifying that, every time one value increases, the other decreases by the same degree) and 1 (signifying the values move in unison). A value of 0 indicates that the two variables are independent. There is strong evidence to suggest that PV is negatively correlated with the overall market. As one economist stated, "PV is free of fuel price risk, and, moreover, has virtually no operating expenses since all costs are in the form of up-front investment outlays... This, of course, does not mean that PV is entirely riskless, but the remaining risk, the so called random or technology risk, is fully diversifiable." This economist goes on further to say, "The value of PV-based electricity... will rise as the returns to other assets are falling" (Awerbuch 2000). This may not always be the case as PV becomes a larger part of the overall energy market.
} 


\section{Lower costs through longer system lifetime}

Although it does not directly lower the cost of capital, increasing PV project lifetime can effectively lower the cost of capital over a given period. Each project investor expects a return on investment over a particular time frame, but in every calculation is some expectation on the total lifetime of a project. Some investors do not assess any value beyond the length of the electricity contract (e.g., PPA) either owing to the risks associated with the electricity price beyond the contract or the unknown lifespan of the system. With R\&D efforts to mitigate those risks, investors can have more certainty about cash flow, and they can model PV projects for longer lifetimes. Conversely, risks may become larger in these areas because of increased uncertainty surrounding future electricity prices or because new products introduced into the marketplace have shorter lifespans. To quantify the effects of lower financing costs achieved through the R\&D efforts described earlier, we used NREL's System Advisor Model (SAM) to model a U.S. utility-scale PV project based on the 2017 utility-scale assumptions described in Fu et al. (2017), for systems built in Kansas City, MO.

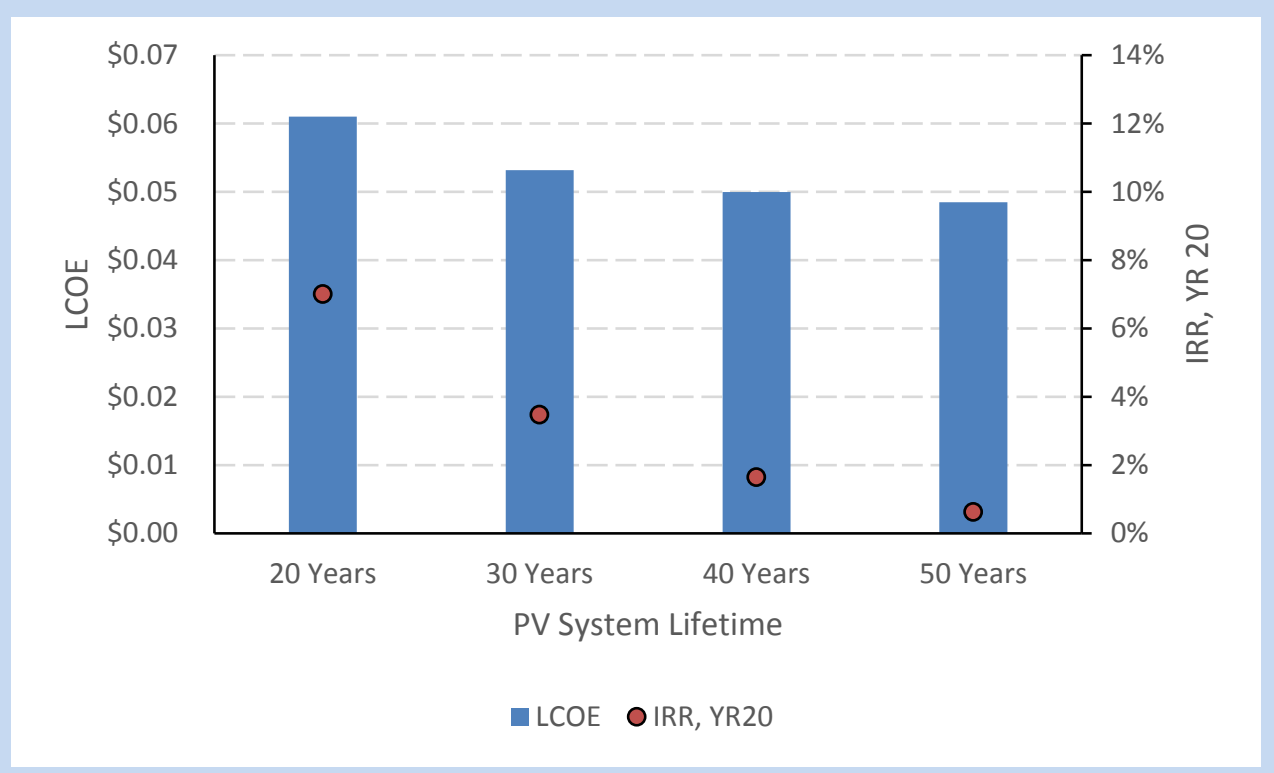

Figure 1. Changes in a utility-scale PV project's LCOE and IRR in year 20 based on system lifetime

As demonstrated in Figure 1, if we assume that a PV system has a 30-year lifetime (as assumed in Fu et al. 2017), then decreasing expected lifetime to 20 years would increase the LCOE by $17 \%$, and increasing expected lifetime to 50 years would reduce LCOE by $10 \%$. The time it takes to achieve a project's necessary internal rate of return (IRR) varies dramatically in these cases as well. If a project's required IRR is 7\%, then the IRR in year 20 of a project with a lifetime of 20 years must be $7 \%$; however, a project with a 50-year lifetime would only require a return a little above $0 \%$ in year 20. In other words, the cost of financing in the first 20 years declines as the project's expected life increases. Although most investors do not have a 50-year time horizon, the value creation (or destruction) caused by a change in lifespan can have an impact on investors' financial hurdles for the initial financing period. 


\subsection{Quantifying R\&D Effects on the Cost of Debt}

Calculating the impact of risk on the cost of debt is different than calculating the impact on the cost of equity. The return on equity is based on the variability in cash flows; if an investment produces more cash flows, the return on equity is greater. However, the debt on a project (interest payments and return of principal) is the same no matter what happens to the underlying cash flows unless the project defaults on its debt. The less volatile the underlying value of a project is, the less likely it will default. In other words, the larger the distribution of possible investment returns, the more likely a default will occur.

Debt is composed of three parts: 1) risk-free return (LIBOR), 2) "swap rate" (the cost of turning the variable, or floating, market rate of risk-free debt into a fixed, long-term rate), and 3) "credit spread" (the premium charged by banks to account for the risk of default). ${ }^{27}$ Assuming that the risk of the project is incorporated solely in the "credit spread" and not in the risk-free return or the swap rate, we can calculate the impact of changes in the volatility of asset value by determining the impact of these changes on the credit spread.

The Merton Model uses the Black-Scholes option pricing theory to calculate the credit spread. The concept behind the Merton model is that equity holders have a "European Call Option" on a company's assets, meaning they have the option, but not the obligation, to buy an asset at an agreed-upon price at a set time in the future. A call option is only exercised if, at that future moment, the asset is worth more than the agreed-upon price. Those purchasing call options effectively limit any risk on an investment, because they only exercise their rights if it is economically beneficial to do so. Those selling call options expose themselves to all the downside risks of the investment, and they are limited in any upside benefits, because - above a certain price - those benefits will go to the purchaser of the option. However, those selling a call option can limit their downside risk by purchasing a put option, meaning they have the option to sell the asset at a specified price at some point in the future.

The call option essentially describes the relationship between the equity and debt of a company. As long as the company is worth more than its debt, equity holders will continue to pay the interest (and often principal) on the debt, giving equity holders the "option" of retaining ownership in the underlying investment. ${ }^{28}$ However, if the value of the company falls below the value of its debt, then the equity holders can choose to stop paying the debt holders, which is equivalent to not exercising their option on the equity investment. The put option is the calculated value of risk that the debt holder is assuming for a potential default. Therefore, the put option to the debt holder is the calculated credit risk of the underlying company; by calculating the value of the put option, the risk premium of the debt can be calculated.

Equation 6, based on the Merton Model, calculates the credit spread of a debt product (Hull et al. 2004, Trück et al. 2004, Kelly et al. 2016). ${ }^{29}$

\footnotetext{
${ }^{27}$ There is also a spread on top of this to provide for the bank offering the loan.

${ }^{28}$ If equity holders stopped paying their debt service, then some or all of the ownership rights to that investment would revert to the debt holders.

${ }^{29}$ The Black-Scholes formula is: $C\left(S_{T}\right)=S_{T} \times N\left(d_{1}\right)-\times \frac{K}{e^{R_{F} \times T}} \times N\left(d_{2}\right)$, where $\mathrm{C}\left(\mathrm{S}_{\mathrm{T}}\right)$ is the price of a call option.
} 
Equation 6. Formula for the credit spread on debt using the Merton Model

$$
\begin{gathered}
s=-\frac{1}{T} \times \ln \left[N\left(d_{2}\right)+\frac{N\left(-d_{1}\right)}{L}\right] \\
L=\frac{\mathrm{K} \times e^{-\left(R_{F} \times T\right)}}{S_{T}} \\
d_{1}=\frac{\ln \left(\frac{S_{T}}{K}\right)+\left(R_{F}+\frac{\sigma^{2}}{2}\right) \times T}{\sigma \times \sqrt{T}} \\
d_{2}=d_{1}-\sigma \times \sqrt{T}
\end{gathered}
$$

$\mathrm{s}=$ calculated credit spread of the debt

$\mathrm{S}_{\mathrm{T}}=$ spot price of the underlying asset (i.e., its value)

$\mathrm{K}=$ strike price of the underlying asset (i.e., the agreed-upon sales price for the option)

$\mathrm{N}(\mathrm{x})=$ cumulative distribution function of the standard normal distribution ${ }^{30}$

$\mathrm{e}=$ irrational number "e," or $2.718 \ldots$

$\mathrm{R}_{\mathrm{F}}=$ expected return on a risk-free investment (e.g., U.S. Treasury bond)

$\sigma=$ underlying asset volatility (i.e., standard deviation of asset value)

$\mathrm{T}=$ time to maturity of the contract

$\ln (\mathrm{x})=$ natural $\log$ of a given number $\mathrm{x}$

$\mathrm{d}_{1}=$ ratio between the present value of option to the current value of the asset (Nielsen 1993)

$\mathrm{d}_{2}=$ risk-adjusted probability that an option will be exercised (Nielsen 1993)

Using Equation 6, we can calculate the impact that an R\&D-driven change in asset volatility can have on the credit spread for a PV asset.

\subsection{Quantifying R\&D Effects on Project Leverage}

As discussed in Section 3.2, R\&D efforts could affect variables that could increase project leverage, but, in a competitive marketplace, it is more likely that an owner will offset an improvement (e.g., reduced system cost) with a reduction in the electricity sales price as projects seek to win contracts. Therefore, although these variables can impact leverage, it is typically better to measure their impact in terms of lower energy prices.

The exception to this case is DSCR, which protects investors from their perceived cash flow risks. Typically, debt providers require that a project's cash flows meet at least two different DSCRs to protect against shortfalls in cash flow that would result in loan default. Owing to interannual changes in insolation, even an ideal PV system will exhibit some degree of variation from expected production. The data uncertainty is analyzed in terms of P50 and P99 values: there is a $50 \%$ chance that a project's cash flows will exceed the P50 value and a 99\% chance they will exceed the P99 value. The relationship between the P50 DSCR and P99 DSCR is summarized in Equation 7.

\footnotetext{
${ }^{30}$ Values for the cumulative standard normal distribution were derived from Kapur and Pecht (2014).
} 
Equation 7. Calculating P50 DSCR with P99 DSCR and standard deviation of debt payments

$$
\operatorname{DSCR}_{P 50}=\frac{\operatorname{DSCR}_{P 99}}{\left[1-\left(\text { standard deviation of debt payments } \times \text { Zscore }_{P 99}\right)\right]}
$$

Using Equation 7, we can calculate the impact that a change in the standard deviation of debt payments can have on the DSCR for a PV asset.

\subsection{Quantifying Analysis and Standardization Effects on Upfront Costs}

Because analysis and standardization efforts, as well as R\&D efforts, can streamline and standardize procedures and documentation, increase customer base, reduce risk, lower operating costs, and save project development time, they can result in lower upfront financing costs for a PV system or pool of systems (e.g., lower interest expense on construction debt through a faster interconnection process, lower professional service fees) or larger financial transactions. Using the data from Table 4, we estimate upfront costs associated with arranging financing for an average financial transaction at $1.1 \phi / \mathrm{W}$ for utility-scale PV projects and $3.1 \varnothing / \mathrm{W}$ for portfolios of residential PV projects, or roughly $1 \%$ of total system costs.

Table 4. Upfront Costs Associated with Arranging Typical Financing

\begin{tabular}{lll}
\hline & Current Costs & Source \\
\hline $\begin{array}{l}\text { Upfront costs associated with } \\
\text { arranging financing (transaction } \\
\text { costs) }\end{array}$ & $\$ 1,100,000$ & Feldman et al. (2016) \\
\hline $\begin{array}{l}\text { Size of portfolio/project } \\
\text { PV system cost per watt (utility- } \\
\text { scale PV) }\end{array}$ & $\$ 1.03$ & Feldman et al. (2016) \\
\hline $\begin{array}{l}\text { Transaction costs per watt (utility- } \\
\text { scale PV) }\end{array}$ & $\$ 0.011$ & Fu et al. (2017) \\
\hline $\begin{array}{l}\text { PV system cost per watt } \\
\text { (residential PV) }\end{array}$ & $\$ 2.80$ & Calculation: $\frac{\text { transaction costs }}{\text { Portfolio size }(\$)} \times P V$ system $\$ / W$ \\
\hline $\begin{array}{l}\text { Transaction costs per watt } \\
\text { (residential PV) }\end{array}$ & $\$ 0.031$ & Fu et al. $(2017)$ \\
\hline
\end{tabular}

Feldman et al. (2016) note that many single transactions exceed $\$ 200$ million in PV assets. If transaction fees could be reduced to the cost of a single legal firm in a transaction full of mature actors, costs could drop to approximately $\$ 250,000$ (Feldman et al. 2013), equivalent to $0.1 \notin / \mathrm{W}$ for utility-scale PV projects and $0.4 ф / \mathrm{W}$ for portfolios of residential PV projects at current PV price levels (for a \$200 million transaction). However, Feldman et al. (2016) also report some transaction costs as high as $\$ 1.7$ million. With a slowdown in the market (which could be due to a lack of financeable projects), the pool of projects may shrink to the point where $\$ 25$ million transactions are the norm; in this instance, $\$ 1.7$ million in transaction costs translates to $7 \varnothing / \mathrm{W}$ for utility-scale PV projects and $19 \phi / \mathrm{W}$ for portfolios of residential PV projects at current PV price levels. 


\section{Results: R\&D, Analysis, and Standardization Impacts on Financing Costs and PV LCOE}

This section uses the methods outlined in Section 4 to measure the potential impacts of R\&D on financing costs and the resulting effects on PV's LCOE. It also compares the financing cost results with financing costs in other industries.

\subsection{Impact of Changing the Cost of Capital}

We estimate the current, low-risk, and high-risk scenario values for the cost of equity for a PV investment using CAPM and data from Table 3 and Table 5.

Table 5. Assumptions Used in CAPM, PV Investment (values annualized unless otherwise stated)

\begin{tabular}{|c|c|c|}
\hline Variable & Value & Source \\
\hline Market Return $\left(\mathrm{R}_{\mathrm{M}}\right)$ & $5.7 \%$ & $\begin{array}{l}\text { Average 15-year return for Fidelity U.S. Bond Index, 2005-2016 } \\
\text { (finance.yahoo.com) }^{31}\end{array}$ \\
\hline $\begin{array}{l}\text { Standard Deviation } \\
\text { of Market Returns } \\
\left(\mathrm{R}_{\mathrm{M}}\right)\end{array}$ & $0.8 \%$ & $\begin{array}{l}\text { Standard deviation of average 15-year return for Fidelity U.S. Bond } \\
\text { Index, 2005-2016 (finance.yahoo.com) }\end{array}$ \\
\hline Risk-free Rate $\left(R_{F}\right)$ & $2.4 \%$ & NERA Economic Consulting (2015) \\
\hline $\begin{array}{l}\text { Standard Deviation } \\
\text { of PV Asset Returns } \\
\text { (Asset Volatility) }\left(R_{A}\right)\end{array}$ & $\begin{array}{l}\text { Current } \\
\text { scenario: } \\
1.4 \% \\
(20 \%)\end{array}$ & $\begin{array}{l}\text { The current } 1.4 \% \text { standard deviation assumes a return volatility of } \\
20 \% \text {, per Table } 3 \text {, and an unlevered equity return of } 7 \% \text { (i.e., } 20 \% x \\
7 \%=1.4 \% \text { ) (Saeger } 2017 \text { ) }\end{array}$ \\
\hline $\begin{array}{l}\text { Correlation } \\
\text { Coefficient }\end{array}$ & $\begin{array}{l}\text { Current } \\
\text { scenario: } \\
0.78\end{array}$ & $\begin{array}{l}\text { Correlation Coefficient } \\
\qquad=\text { Unlevered Beta } \times \frac{\text { Standard Deviation }\left(R_{M}\right)}{\text { Standard Deviation }\left(R_{A}\right)}\end{array}$ \\
\hline Unlevered BetaAUL & $\begin{array}{l}\text { Current } \\
\text { scenario: } \\
1.39\end{array}$ & 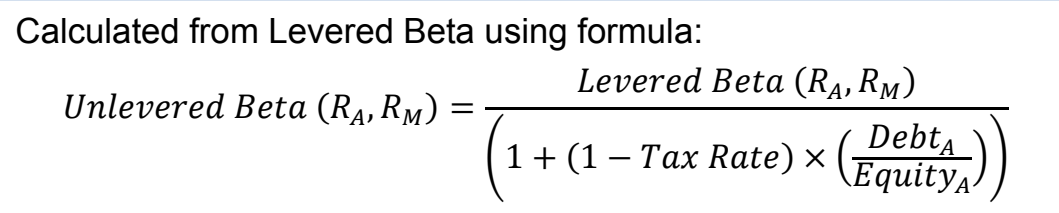 \\
\hline Debt / Equity Ratio & 0.66 & Feldman et al. $(2016)^{32}$ \\
\hline Tax Rate ${ }^{33}$ & $35 \%$ & U.S. corporate tax rate \\
\hline Levered Beta & $\begin{array}{l}\text { Current } \\
\text { scenario: } \\
1.99\end{array}$ & $\begin{array}{l}\text { Calculated using the formula for CAPM, assuming an unlevered } \mathrm{R}_{\mathrm{A}} \\
\text { of } 7.0 \% \text { (Saeger 2017). } R_{A}=R_{F}+B_{A L} \times\left(R_{M}-R_{F}\right)\end{array}$ \\
\hline
\end{tabular}

\footnotetext{
${ }^{31}$ Most CAPM analyses use the overall stock market (e.g., the S\&P 500 index) as a market return input. We use the U.S. Bond Index because PV investments resemble investments in debt instruments in many ways, such as a large upfront payment, long-term payback, and price volatility based on changes in competing investment opportunities.

${ }^{32}$ Although an increase of debt on a project would increase the calculated equity return (by increasing Beta), the overall cost of capital to the project would be lowered, because debt typically costs less than equity.

33 Analysis in this report was performed before a change to the corporate tax rate in late 2017.
} 
The results show a cost of equity of $9.0 \%$ in the current scenario, fairly consistent with the value reported in Feldman et al. (2016). In the low-risk scenario, the cost of equity declines to $5.7 \%$. In the high-risk scenario, the cost of equity increases to $17.2 \%$.

We estimate the current, low-risk, and high-risk values for the cost of debt for a PV investment using the Merton Model and data from Table 3 and Table 6.

Table 6. Assumptions Used in the Merton Model, PV Investment

\begin{tabular}{|c|c|c|}
\hline Variable & Value & Source \\
\hline $\begin{array}{l}\text { Value of PV asset } \\
\text { (ST) }\end{array}$ & $\$ 76$ & $\begin{array}{l}\text { Unlike many firms that operate in perpetuity, a PV asset has a finite } \\
\text { life, and therefore its equity value will decrease over time. We } \\
\text { reduce the value of the underlying asset by its reduction in lifetime } \\
\text { over the course of the debt term. We assume an original PV asset } \\
\text { value of } \$ 100 \text {, a } 30 \text {-year lifetime, and a } 7 \text {-year debt term: } \$ 100 \times \\
{[(30-7) / 30]=\$ 76 \text {. }}\end{array}$ \\
\hline Value of the debt $(\mathrm{K})$ & $\$ 40$ & $\begin{array}{l}\text { We assume an original PV asset value of } \$ 100 \text { and a leverage } \\
\text { ratio of } 40 \% \text { (Feldman et al. 2016). }\end{array}$ \\
\hline Risk-free Rate $\left(R_{F}\right)$ & $2.4 \%$ & NERA Economic Consulting (2015) \\
\hline $\begin{array}{l}\text { Asset Volatility } \\
\text { (Standard Deviation) } \\
\left(\mathrm{R}_{\mathrm{A}}\right)\end{array}$ & $\begin{array}{l}\text { Current } \\
\text { scenario: } \\
20 \%\end{array}$ & Table 3 \\
\hline $\begin{array}{l}\text { Time to maturity of } \\
\text { contract }(T)\end{array}$ & 7 years & Feldman et al. (2016) \\
\hline Debt / Equity Ratio & 0.66 & Feldman et al. (2016) \\
\hline
\end{tabular}

The results show a debt risk premium of 30 basis points in the current scenario. In the low-risk scenario, the debt risk premium declines to 0.2 basis points. In the high-risk scenario, the debt risk premium increases to 386 basis points. Adding the 30 basis points in the current scenario to the current swap rate of $2.25 \%$ and the risk free rate (LIBOR) of 1\% (Martin 2017), we calculate a total cost of debt of 3.5\%. This value is lower than the costs reported in Feldman et al. (2016): $4.3 \%$ for utility-scale PV projects and 4.8\% for distributed PV projects. Martin (2017) estimates the credit spread for PV projects in 2017 to range from 162.5 to 200 basis points (although the credit spread represents a larger spread than just the credit risk). Therefore, either the Merton Model significantly underestimates the credit spread of a debt project, the market significantly overestimates the volatility in value of a PV system (or it is taking a large profit spread), or our analysis has not accounted for all the perceived volatility in value of a PV system. Further research on the volatility in value of a PV system is needed.

Using our calculated costs of equity and debt (based on the equity return and asset value volatilities in Table 3), an assumed debt level of 40\% (i.e., a constant DSCR), and NREL's SAM, we calculate LCOEs for U.S. residential and utility-scale PV systems. ${ }^{34}$ As shown in Figure 2, R\&D-driven changes to the costs of equity and debt could lower LCOE by as much as

\footnotetext{
${ }^{34}$ Additional LCOE assumptions are based on the 2017 residential and utility-scale assumptions described in Fu et al. (2017) for systems in Phoenix, Kansas City, and New York City.
} 
$21 \%$ (comparing the low-risk scenario with the current scenario) or prevent an increase in LCOE of as much as $80 \%$ (comparing the high-risk scenario with the current scenario).

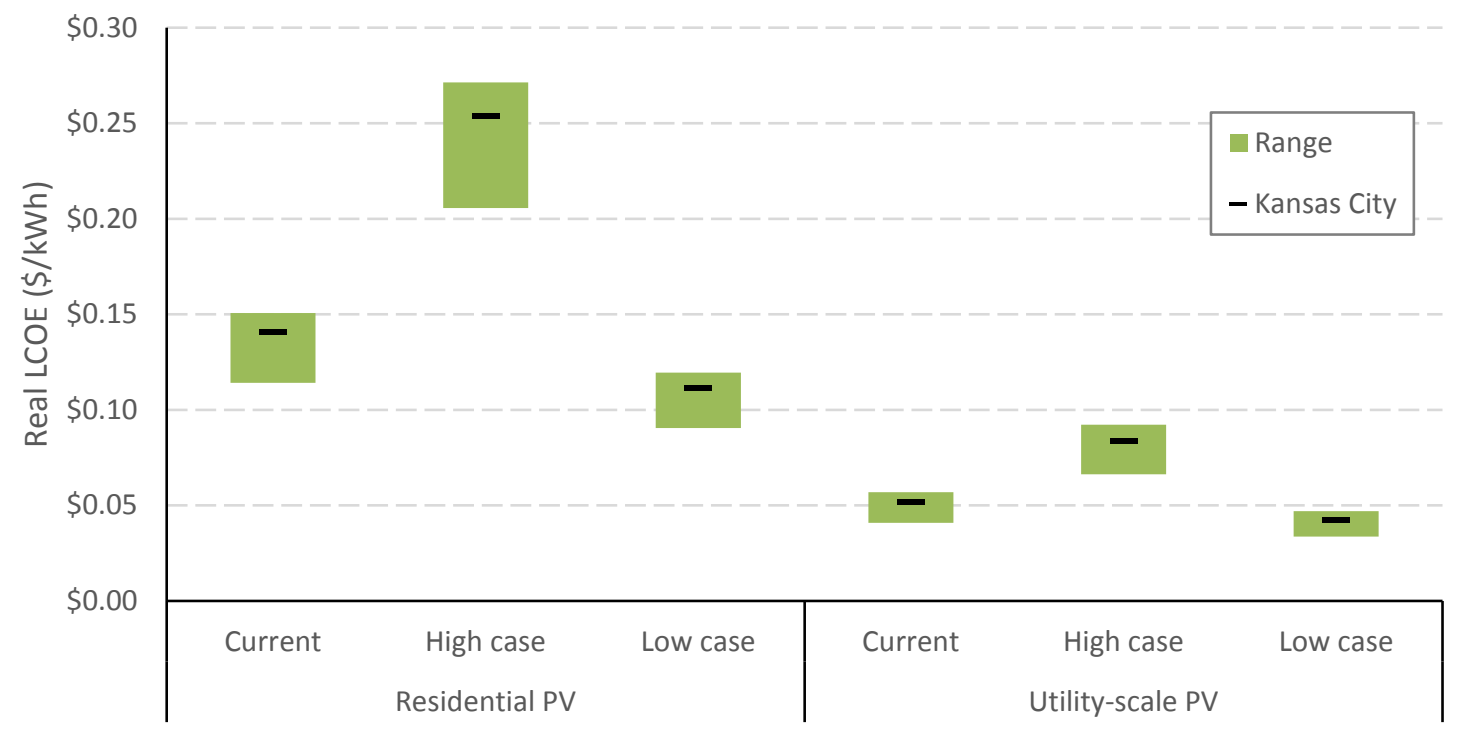

The lower end of the range represents the LCOE for Phoenix, and the upper end of the range represents the LCOE for New York City. These values represent the unsubsidized cost of electricity and therefore do not include any federal or state incentives.

Figure 2. LCOE of residential and utility-scale PV under the current, low-risk, and high-risk scenarios for the costs of equity and debt (variable equity and debt costs)

\subsection{Impact of Changing the DSCR}

Using the method described in Section 4.4 and data from Table 3, we estimate DSCRs for a PV investment of 1.30 in the current scenario, 1.08 in the low-risk scenario, and 1.87 in the high-risk scenario. Using these assumptions, the current-scenario costs of equity $(9.0 \%)$ and debt (3.5\%) from Section 5.1, and NREL's SAM, we calculate the leverage and LCOE of U.S. residential and utility-scale PV systems. ${ }^{35}$ When the DSCR changes from 1.30 to 1.08 , the amount of debt increases from $55 \%$ to $62 \%$ of project costs. When the DSCR changes to 1.87 , the amount of debt decreases to $43 \%$ of project costs. ${ }^{36}$ As shown in Figure 3, R\&D-driven changes to DSCR could lower LCOE by as much as $5 \%$ or prevent an increase in LCOE of as much as $10 \%$.

\footnotetext{
${ }^{35}$ Additional LCOE assumptions are based on the 2017 residential and utility-scale assumptions described in Fu et al. (2017) for systems in Phoenix, Kansas City, and New York City.

${ }^{36}$ These calculations are based on an unsubsidized cost of electricity and do not include the $30 \%$ federal investment tax credit, so the amount of leverage in the current scenario (55\%) is higher than the amount seen in the marketplace. If we include the $30 \%$ federal tax credit in our model, the amount of debt drops to $35 \%$ - consistent with market values reported in Feldman et al. (2016). However, both with and without a federal tax credit, a reduction in the DSCR from the current scenario to the low risk scenario results in a $12 \%$ increase in leverage.
} 


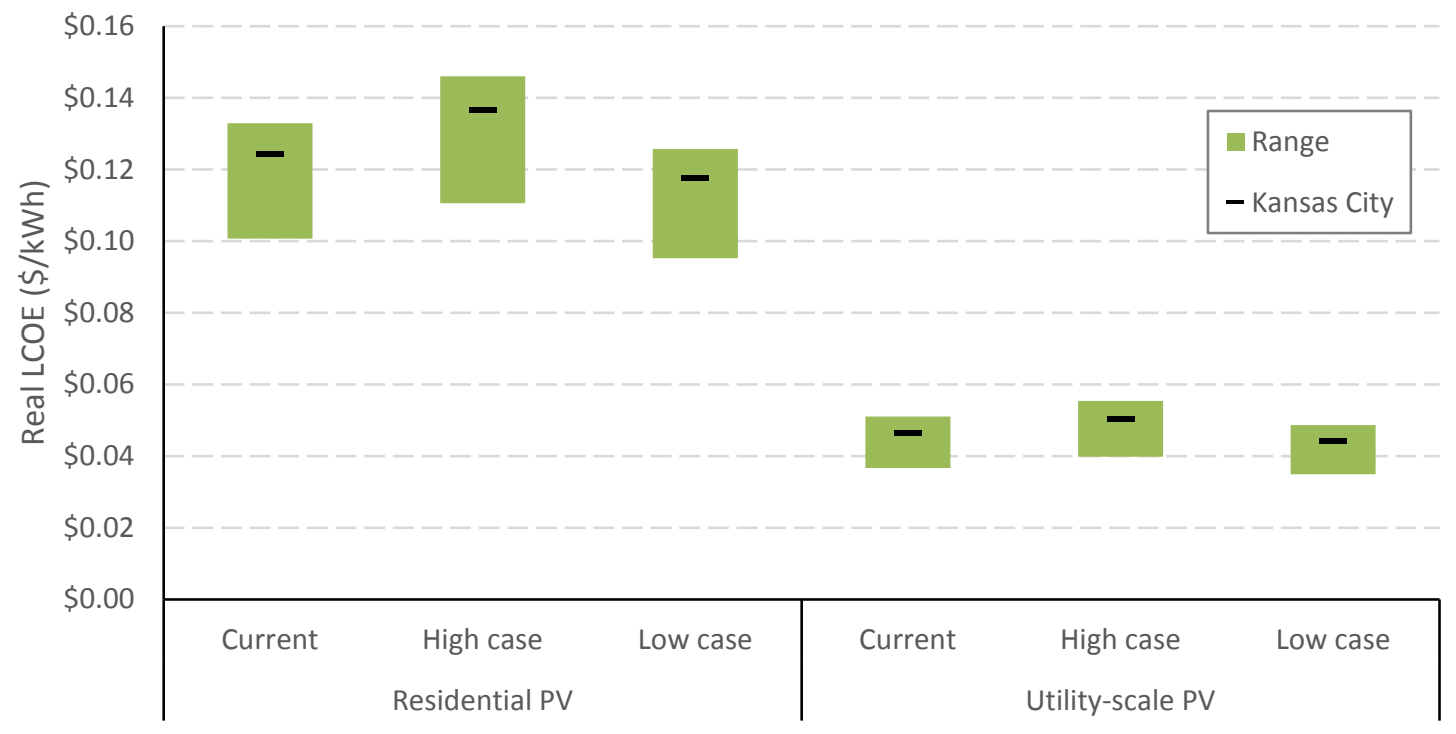

The lower end of the range represents the LCOE for Phoenix, and the upper end of the range represents the LCOE for New York City. These values represent the unsubsidized cost of electricity and therefore do not include any federal or state incentives.

Figure 3. LCOE of residential and utility-scale PV under the current, low-risk, and high-risk scenarios (variable DSCR)

\subsection{Impact of Changing Upfront Costs}

Based on the analysis in Section 4.5, we estimate that analysis and standardization efforts could reduce upfront transaction fees from $1.1 \phi / \mathrm{W}$ to $0.1 \phi / \mathrm{W}$ for utility-scale PV projects, and from $3.1 \phi / \mathrm{W}$ to $0.4 \phi / \mathrm{W}$ for portfolios of residential PV projects at current PV price levels. Such efforts also might prevent an increase in costs and a slowdown in the market that would increase transaction costs to $7 \phi / \mathrm{W}$ for utility-scale PV projects and $19 \phi / \mathrm{W}$ for portfolios of residential PV projects at current PV price levels.

Using these assumptions, the current-scenario costs of equity $(9.0 \%)$ and debt $(3.5 \%)$ from Section 5.1, an assumed debt level of 40\%, and NREL's SAM, we calculate LCOEs for U.S. residential and utility-scale PV systems. ${ }^{37}$ As shown in Figure 4, analysis- and standardizationdriven changes to upfront financing costs could lower LCOE by approximately $1 \%$ in a lowupfront-cost scenario or prevent an increase in LCOE of approximately $5 \%$ in a high-upfrontcost scenario.

${ }^{37}$ Additional LCOE assumptions are based on the 2017 residential and utility-scale assumptions described in Fu et al. (2017) for systems in Phoenix, Kansas City, and New York City. 


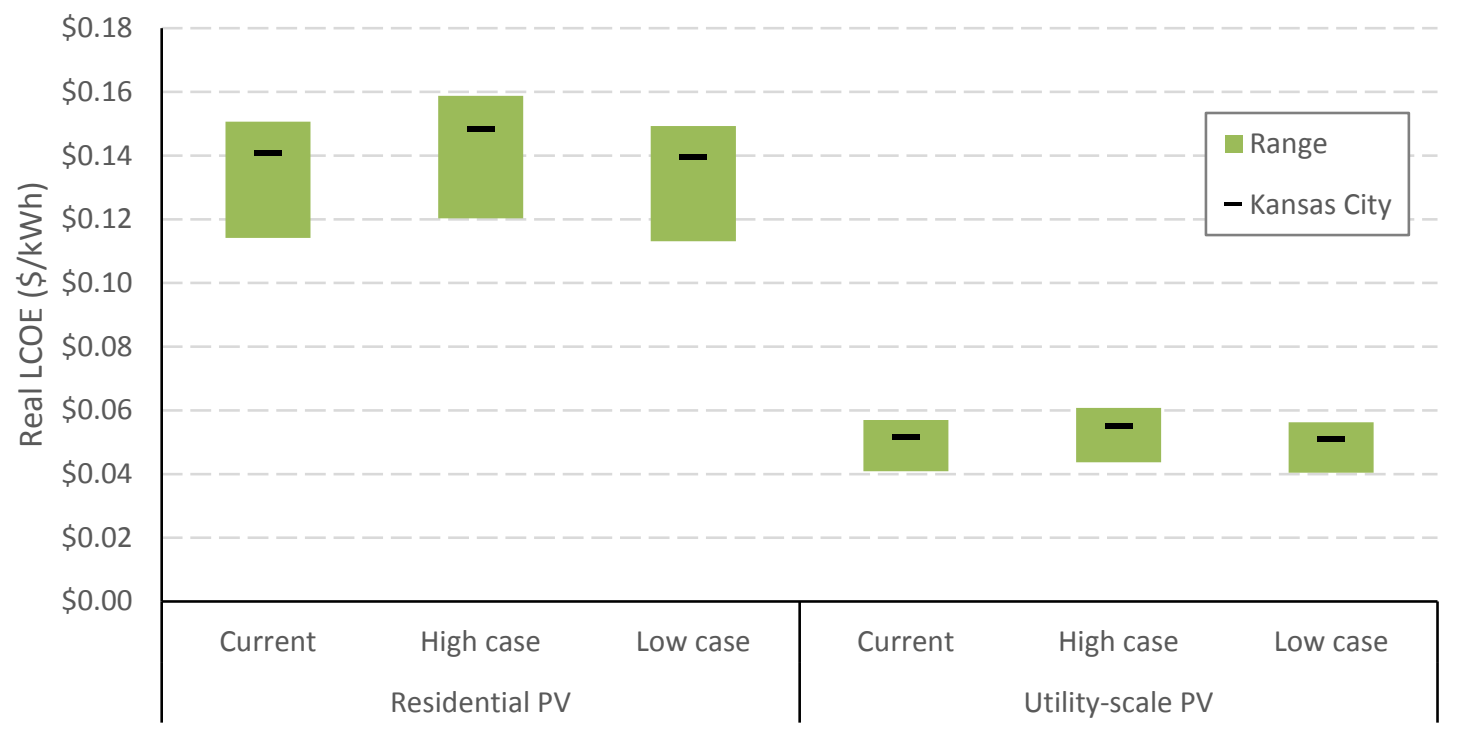

The lower end of the range represents the LCOE for Phoenix, and the upper end of the range represents the LCOE for New York City. These values represent the unsubsidized cost of electricity and therefore do not include any federal or state incentives.

Figure 4. LCOE of residential and utility-scale PV under the current, low-risk, and high-risk scenarios (variable upfront costs)

\subsection{Summary of R\&D, Analysis, and Standardization Impacts on PV Financing Costs and LCOE}

Table 7 summarizes the various R\&D, analysis, and standardization activities discussed that could affect PV financing costs. 
Table 7. Summary of R\&D, Analysis, and Standardization Impacts on PV Financing Cost

\begin{tabular}{|c|c|c|c|c|}
\hline \multirow[b]{2}{*}{ R\&D Activity } & \multicolumn{4}{|c|}{ Effect on Financing Cost } \\
\hline & $\begin{array}{l}\text { Lower risk } \\
\text { premium }\end{array}$ & $\begin{array}{l}\text { Increased } \\
\text { leverage }\end{array}$ & $\begin{array}{l}\text { Reduced } \\
\text { upfront costs }\end{array}$ & $\begin{array}{l}\text { Reduced time to } \\
\text { close financing }\end{array}$ \\
\hline \multicolumn{5}{|l|}{ Technology R\&D } \\
\hline Durability & $\sqrt{ }$ & $\sqrt{ }$ & $\sqrt{ }$ & $\sqrt{ }$ \\
\hline Reliability & $\sqrt{ }$ & $\sqrt{ }$ & $\sqrt{ }$ & $\sqrt{ }$ \\
\hline Certainty of production over time & $\sqrt{ }$ & $\sqrt{ }$ & $\sqrt{ }$ & $\sqrt{ }$ \\
\hline Improved module testing & $\sqrt{ }$ & $\sqrt{ }$ & $\sqrt{ }$ & $\sqrt{ }$ \\
\hline Lower system price & & & $\sqrt{ }$ & \\
\hline \multicolumn{5}{|l|}{ Integration R\&D } \\
\hline Improved production forecasting & $\sqrt{ }$ & $\sqrt{ }$ & $\sqrt{ }$ & $\sqrt{ }$ \\
\hline Advanced inverter designs & $\sqrt{ }$ & $\sqrt{ }$ & $\sqrt{ }$ & $\sqrt{ }$ \\
\hline Improved communications & $\sqrt{ }$ & $\sqrt{ }$ & $\sqrt{ }$ & $\sqrt{ }$ \\
\hline $\begin{array}{l}\text { More integrated technology and } \\
\text { systems design }\end{array}$ & $\sqrt{ }$ & $\sqrt{ }$ & $\sqrt{ }$ & $\sqrt{ }$ \\
\hline \multicolumn{5}{|c|}{ Business practices analysis and standardization activities } \\
\hline $\begin{array}{l}\text { Aggregated system performance and } \\
\text { payment history }\end{array}$ & $\sqrt{ }$ & & $\sqrt{ }$ & $\sqrt{ }$ \\
\hline Expanded new sources of capital & $\sqrt{ }$ & & & \\
\hline Lower O\&M costs & & $\sqrt{ }$ & $\sqrt{ }$ & \\
\hline Increased available customer base & & & $\sqrt{ }$ & $\sqrt{ }$ \\
\hline $\begin{array}{l}\text { Streamlined processes, standardized } \\
\text { procedures and documentation }\end{array}$ & & & $\sqrt{ }$ & $\sqrt{ }$ \\
\hline
\end{tabular}

To estimate the full impact that R\&D, analysis, and standardization activities could have on PV system financing costs, we combine the impacts from changes in equity and debt risk premiums, project leverage, and upfront financing costs. However, as noted in Section 4, the costs of individual factors are influenced by other factors. For example, increased leverage causes more risk to equity and debt investors, which pushes their returns higher. To harmonize the various elements, we iterated among the models until the leverage in the SAM models used to calculate LCOE was consistent with the leverage used to calculate the cost of equity and the cost of debt in CAPM and the Merton Model. The results of this calculation are summarized in Table 8. 
Table 8. Summary of Financing Terms in the Current, Low-Risk, and High-Risk Scenarios, after Leverage Adjustment

\begin{tabular}{|c|c|c|c|}
\hline & Current & $\begin{array}{l}\text { Scenario } \\
\text { Low Risk }\end{array}$ & High Risk \\
\hline Cost of equity & $10.9 \%$ & $6.9 \%$ & $19.5 \%$ \\
\hline Risk premium* & $1.0 \%$ & $0.1 \%$ & $4.9 \%$ \\
\hline Swap spread* & $2.25 \%$ & $2.25 \%$ & $2.25 \%$ \\
\hline LIBOR* & $1.0 \%$ & $1.0 \%$ & $1.0 \%$ \\
\hline Total cost of debt & $4.2 \%$ & $3.3 \%$ & $8.2 \%$ \\
\hline DSCR & 1.30 & 1.08 & 1.87 \\
\hline Utility-scale PV transaction costs ( $\$ / W)$ & $\$ 0.01$ & $\$ 0.00$ & $\$ 0.07$ \\
\hline Residential PV transaction costs $(\$ / W)$ & $\$ 0.03$ & $\$ 0.00$ & $\$ 0.19$ \\
\hline Leverage & $56.5 \%$ & $59.4 \%$ & $50.2 \%$ \\
\hline
\end{tabular}

* Risk premium, swap spread, and LIBOR are components of the total cost of debt.

Using these assumptions and NREL's SAM, we calculate the LCOE of U.S. residential and utility-scale PV systems. ${ }^{38}$ As shown in Figure 5, R\&D-driven changes to financing costs could lower PV LCOE by as much as $21 \%$ (comparing the low-risk scenario with the current scenario), or prevent an increase in LCOE of as much as $80 \%$ (comparing the high-risk scenario with the current scenario).

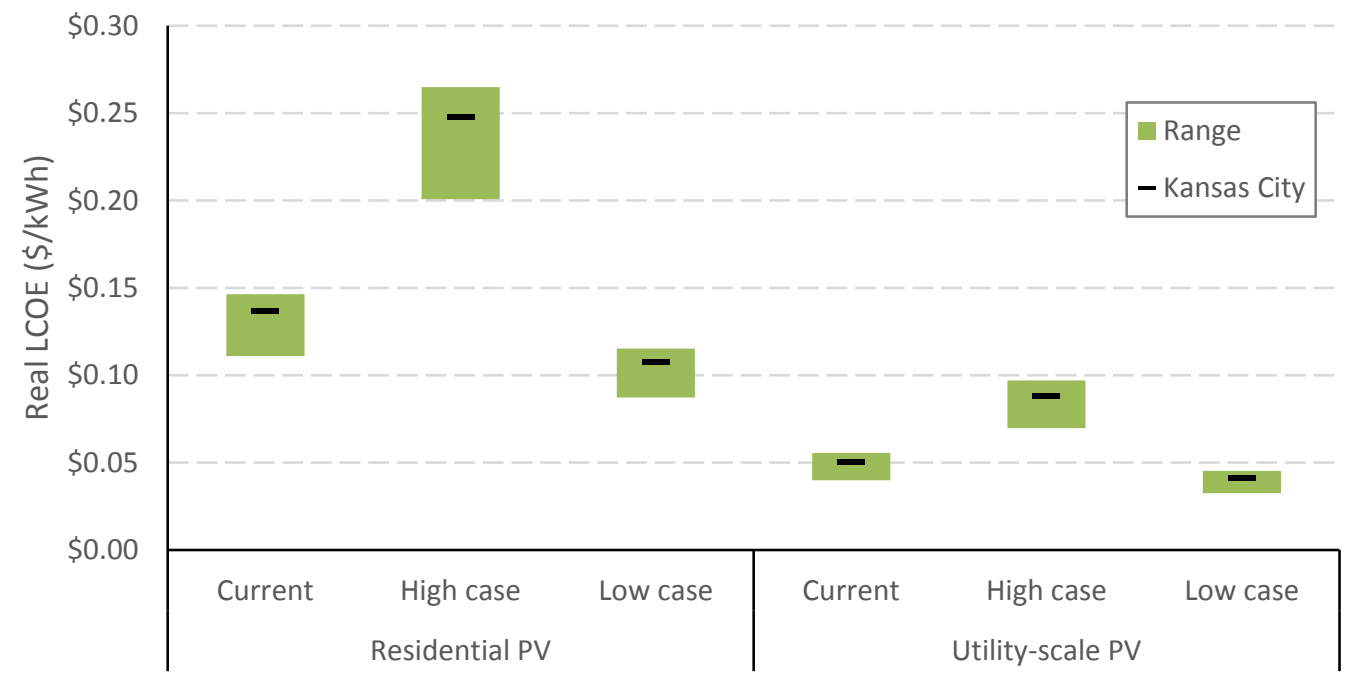

The lower end of the range represents the LCOE for Phoenix, and the upper end of the range represents the LCOE for New York City. These values represent the unsubsidized cost of electricity and therefore do not include any federal or state incentives.

Figure 5. LCOE of residential and utility-scale PV under the current, low-risk, and high-risk scenarios (combined impacts from changes in equity and debt risk premiums, project leverage, and upfront financing costs, after leverage adjustment)

${ }^{38}$ Additional LCOE assumptions are based on the 2017 residential and utility-scale assumptions described in Fu et al. (2017) for systems in Phoenix, Kansas City, and New York City. 


\subsubsection{Comparing Financing Costs across Industries}

Although our calculations estimate possible dramatic changes to the cost of financing, other data suggest that our low risk estimates are consistent with the cost of capital for other industries with low risk profiles, such as real estate (Feldman and Settle 2013) and utilities. Damodaran (2017) calculates that the average WACC for public companies in the utility (water and general), real estate investment trust (REIT), ${ }^{39}$ and railroad sectors ranges from 3.5\% to 5.9\%, compared with a WACC of $4.1 \%$ in our low-risk scenario (Table 9). ${ }^{40}$

Table 9. WACC Values by Sector

\begin{tabular}{lllll}
\hline & Cost of equity & Cost of debt & Leverage & WACC \\
\hline Utility (general) & $4.6 \%$ & $3.1 \%$ & $40.6 \%$ & $3.5 \%$ \\
\hline Utility (water) & $6.1 \%$ & $3.5 \%$ & $30.3 \%$ & $4.9 \%$ \\
\hline REIT & $6.6 \%$ & $3.1 \%$ & $44.3 \%$ & $4.5 \%$ \\
\hline Transportation (railroads) & $6.9 \%$ & $3.5 \%$ & $21.8 \%$ & $5.9 \%$ \\
\hline PV assets, low risk & $6.9 \%$ & $3.3 \%$ & $59.4 \%$ & $4.1 \%$ \\
\hline
\end{tabular}

Source (non-PV assets): Damodaran (2017)

Our calculated higher-end financing costs are also consistent with observed values. Without further R\&D, investment in PV assets may become riskier, with investment coming exclusively from private sectors, such as mezzanine debt $(10 \%-24 \%$ cost of capital) and private equity (20\%-28\% cost of capital) (Everett 2017). The costs of debt (8.2\%) and equity (19.5\%) under our high-risk scenario fall slightly below these ranges.

\footnotetext{
${ }^{39}$ A significant portion of assets owned by REIT and railroad companies are considered real estate.

${ }^{40}$ WACC is not a perfect tool for assessing the cost of capital for PV projects, because the formula assumes a consistent level of debt and equity over time. PV assets often have different levels of equity and debt investors over a project's lifetime, which effectively increases the cost of capital.
} 


\section{Conclusions}

Although inherent risks and transactional costs will always exist with PV investments, R\&D, analysis, and standardization activities can help reduce and remove many PV-related risks and procedures. We estimate that R\&D-driven reductions in financing costs could reduce PV's LCOE by $21 \%$, or at least prevent the LCOE from rising by as much as $80 \%$ owing to increased uncertainty in the marketplace.

Financing costs are fundamentally driven by expectations about risk and return as well as the friction necessary to complete a financing transaction. The more certain financiers are of receiving cash flows from projects - and the less variability is expected - the lower the cost of financing. $\mathrm{R} \& \mathrm{D}$ focused on improvements in technology, system integration, and business practices can create more certainty and reduce expected variability in energy production and the resulting cash flow for the life of PV projects. Further, R\&D activity that adds to or sustains the consumer and grid value of PV assets could result in higher investor returns with less expected risk - and thus lower PV financing costs.

The vast majority of financial transactions involving PV assets are private, and it is difficult to know the volatility of their returns. The assumed volatilities summarized in this report are based on limited data, many of which come from third-party-ownership distributed PV transactions, in particular U.S. regions. It is likely that different market segments (e.g., host-owned residential $\mathrm{PV}$, utility-owned PV) have different volatility ranges. The industry would benefit from more data and improved methods for assessing uncertainties/volatilities surrounding PV cash flow and asset value. In particular, our analysis would benefit from more differentiation between uncertainties in the utility and rooftop PV sectors as well as more information about regulatory uncertainty, the value of competing electricity, customer credit risk, and electricity production uncertainty. 


\section{References}

Andrews, R.W., J.S. Stein, C. Hansen, and D. Riley. 2014. "Introduction to the Open Source PV_LIB for Python Photovoltaic System Modelling Package.” Presented at the IEEE 40th Photovoltaic Specialists Conference (PVSC). http://energy.sandia.gov/wpcontent/gallery/uploads/PV LIB Python final SAND2014-18444C.pdf

Awerbuch, S. 2000. "Investing in Renewables: Risk Accounting and the Value of New Technology." Prepared for Energy Policy, Special Issue on Renewables. http://www.awerbuch.com/shimonpages/shimondocs/solar-roofs-policy.pdf

Bantz, R. 1981. "The Relationship Between Return and Market Value of Common Stocks." Journal of Financial Economics 9(1): 3-18.

Barbose, G., J. Miller, B. Sigrin, E. Reiter, K. Cory, J. McLaren, J. Seel, A. Mills, N. Darghouth, and A. Satchwell. 2016. On the Path to SunShot: Utility Regulatory and Business Model Reforms for Addressing the Financial Impacts of Distributed Solar on Utilities. NREL/TP-6A20-65670. Golden, CO: National Renewable Energy Laboratory. http://www.nrel.gov/docs/fy16osti/65670.pdf

Basu, S. 1977. "Investment Performance of Common Stocks in Relation to their Price-Earnings Ratios: A Test of the Efficient Market Hypothesis." Journal of Finance (June): 663-682.

Bellini, E. 2017. "Spanish PV Could Go Merchant but Market Must Change.” PV Magazine, November 3, 2017.

Bolinger, M., and J. Seel. 2016. Utility-Scale Solar 2015: An Empirical Analysis of Project Cost, Performance, and Pricing Trends in the United States. Berkeley, CA: Lawrence Berkeley National Laboratory.

Chaudhry, R. 2010. “The Search for Lowest Cost Capital.” Project Finance News Wire, July 2010.

CohnReznick. 2017. U.S. Renewable Energy Brief: The Tax Equity Landscape, Summer 2017. New York: CohnReznick.

Damodaran, A. 2017. "Cost of Equity and Capital: U.S. Companies." Data website, updated January 5, 2017. http://www.stern.nyu.edu/ adamodar/New Home Page/data.html.

Dempsey, M. 2013. "The Capital Asset Pricing Model (CAPM): The History of a Failed Revolutionary Idea in Finance?" Abacus 49: 7-23. doi:10.1111/j.1467-6281.2012.00379.

Denholm, P., K. Clark, and M. O'Connell. 2016. On the Path to SunShot: Emerging Issues and Challenges in Integrating High Levels of Solar into the Electrical Generation and Transmission System. NREL/TP-6A20-65800. Golden, CO: National Renewable Energy Laboratory. http://www.nrel.gov/docs/fy16osti/65800.pdf. 
Denholm, P., R. Margolis, B. Palmintier, C. Barrows, E. Ibanez, L. Bird, and J. Zuboy. 2014. Methods for Analyzing the Benefits and Costs of Distributed Photovoltaic Generation to the U.S. Electric Utility System. NREL/TP-6A20-62447. Golden, CO: National Renewable Energy Laboratory.

DOE (U.S. Department of Energy). 2016. The SunShot Initiative's 2030 Goal: $3 \phi$ per Kilowatt Hour for Solar Electricity. DOE/EE-1501. Washington, DC: DOE.

Doyle, C., A. Truitt, D. Inda, R. Lawrence, R. Lockhart, and M. Golden. 2015. SAPC Best Practices in PV System Installation. NREL/SR-6A20-63234. Golden, CO: National Renewable Energy Laboratory.

EIA (U.S. Energy Information Administration). 2016. Form EIA-861 Annual Survey Data. Release date: October 12, 2016. Washington, DC: EIA.

Everett, C. 2017. 2017 Capital Markets Report: Pepperdine Private Capital Markets Project. Malibu, CA: Pepperdine University Graziadio School of Business and Management.

Feldman, D., and M. Bolinger. 2016. On the Path to SunShot: Emerging Opportunities and Challenges in Financing Solar. NREL/TP-6A20-65638. Golden, CO: National Renewable Energy Laboratory.

Feldman, D., A.M. Brockway, E. Ulrich, and R. Margolis. 2015. Shared Solar: Current Landscape, Market Potential, and the Impact of Federal Securities Regulation. NREL/TP-6A2063892. Golden, CO: National Renewable Energy Laboratory.

Feldman, D., B. Friedman, and R. Margolis. 2013. Financing, Overhead, and Profit: An InDepth Discussion of Costs Associated with Third-Party Financing of Residential and Commercial Photovoltaic Systems. NREL/TP-6A20-60401. Golden, CO: National Renewable Energy Laboratory.

Feldman, D., T. Lowder, and P. Schwabe. 2016. Terms, Trends, and Insights: PV Project Finance in the United States, 2016. NREL/BR-6A20-66991. Golden, CO: National Renewable Energy Laboratory. https://www.nrel.gov/docs/fy16osti/66991.pdf

Feldman, D., and E. Settle. 2013. Master Limited Partnerships and Real Estate Investment Trusts: Opportunities and Potential Complications for Renewable Energy. NREL/TP-6A2060413. Golden, CO: National Renewable Energy Laboratory.

Fu, R., D. Chung, T. Lowder, D. Feldman, K. Ardani, and R. Margolis. 2016. U.S. Solar Photovoltaic System Cost Benchmark: Q1 2016. NREL/TP-6A20-66532. Golden, CO: National Renewable Energy Laboratory

Fu, R., D. Feldman, R. Margolis, and K. Ardani. 2017. U.S. Solar Photovoltaic System Cost Benchmark: Q1 2017. NREL/TP-6A20-68925. Golden, CO: National Renewable Energy Laboratory. 
Habte, A., M. Sengupta, and A. Lopez. 2017. Evaluation of the National Solar Radiation Database (NSRDB): 1998-2015. NREL/TP-5D00-67722. Golden, CO: National Renewable Energy Laboratory.

Hull, J., I. Nelken, and A. White. 2004. "Merton Model, Credit Risk, and Volatility Skews." Journal of Credit Risk 1(1): 05.

IEA-ETSAP and IRENA (International Energy Agency Energy Technology Systems Analysis Programme and International Renewable Energy Agency). 2013. Solar Photovoltaics

Technology Brief. Technology Brief E11 - January 2013. https://www.irena.org/DocumentDownloads/Publications/IRENAETSAP\%20Tech\%20Brief\%20E11\%20Solar\%20PV.pdf

Jordan, D., and S. Kurtz. 2012. "Photovoltaic Degradation Rates: An Analytical Review." NREL/JA-5200-51664. Golden, CO: National Renewable Energy Laboratory.

Kapur, K.C., and M. Pecht. 2014. "Appendix C: Table for Cumulative Standard Normal Distribution." In Reliability Engineering (Wiley Online Library). New York: Wiley. http://onlinelibrary.wiley.com/doi/10.1002/9781118841716.app3/pdf

KBRA (Kroll Bond Rating Agency). 2015a. U.S. Structure Finance ABS Presale Report: SolarCity FTE Series 1, LLC, Series 2015-A. December 11, 2015.

KBRA (Kroll Bond Rating Agency). 2015b. U.S. Structure Finance ABS Presale Report: Sunrun Callisto Issuer 2015-1, LLC, Series 2015-1. July 23, 2015.

KBRA (Kroll Bond Rating Agency). 2015c. U.S. Structure Finance ABS Presale Report: SolarCity LMC Series IV, LLC, Series 2015-1. July 28, 2015.

Kelly, B., G. Manzon, and D. Palhares. 2016. Credit Implied Volatility. University of Chicago Booth School of Business.

Köntges, M., S. Kurtz, C. Packard, and U. Jahn. 2014. Review of Failures of Photovoltaic Modules. IEA-PVPS T13-01:2014. International Energy Agency Photovoltaic Power Systems Programme.

Kuitche, J. 2014. A Statistical Approach to Solar Photovoltaic Module Lifetime Prediction. Arizona State University.

Kürschner, M. 2008. Limitations of the Capital Asset Pricing Model (CAPM). GRIN Verlag.

Kurtz, S., J. Wohlgemuth, M. Kempe, N. Bosco, P. Hacke, D. Jordan, D.C. Miller, T.J. Silverman, N. Phillips, T. Earnest, and R. Romero. 2013a. Photovoltaic Module Qualification Plus Testing. NREL/TP-5200-60950. Golden, CO: National Renewable Energy Laboratory. https://www.nrel.gov/docs/fy14osti/60950.pdf 
Kurtz, S., E. Riley, J. Newmiller, T. Dierauf, A. Kimber, J. McKee, R. Flottemesch, and P. Krishnani. 2013b. Analysis of Photovoltaic System Energy Performance Evaluation Method. NREL/TP-5200-60628. Golden, CO: National Renewable Energy Laboratory.

Martin, K. 2010. "Update: Tax Equity and Debt Markets.” Project Finance News Wire, February 2010.

Martin, K. 2017. “Cost of Capital: 2017 Outlook.” Project Finance NewsWire, February 2017.

Merton, R. 1973. “An Intertemporal Capital Asset Pricing Model.” Econometrica 41(5): 867887.

Meydbray, J., and F. Dross. 2017. PV Module Reliability Scorecard Report 2017. DNV

Mills, A., and R. Wiser. 2012. Changes in the Economic Value of Variable Generation at High Penetration Levels: A Pilot Risk Study of California. LBNL-5445E. Berkeley, CA: Lawrence Berkeley National Laboratory.

Mullins, D. 1982. "Does the Capital Asset Pricing Model Work." Harvard Business Review. (January-February): 105-114.

NERA Economic Consulting. 2015. Electricity Generation Costs and Hurdle Rates Lot 1: Hurdle Rates Update for Generation Technologies. NERA Economic Consulting.

Nielsen, L.T. 1993. "Understanding N (d1) and N (d2): Risk-Adjusted Probabilities in the BlackScholes Model." Finance 14: 95-106.

O’Sullivan, F., and C. Warren. 2016. Solar Securitization: An Innovation in Renewable Energy Finance. MITEI-WP-2016-05. Cambridge, MA: MIT Energy Initiative.

Roselund, C., and B.D. Lopez. 2017a. "Solar Goes Corporate: The Rise of the Bilateral PPA." PV Magazine, March 20, 2017.

Roselund, C., and B.D. Lopez. 2017b. "Breaking New Ground.” PV Magazine, April 23, 2017.

Ryberg, D.S., J. Freeman, and N. Blair. 2015. Quantifying Interannual Variability for Photovoltaic Systems in PVWatts. NREL/TP-6A20-64880. Golden, CO: National Renewable Energy Laboratory. http://www.nrel.gov/docs/fy16osti/64880.pdf

Saeger, J. 2017. "EIA Energy Conference, 2017: The Cost of Capital for Renewable Generation Capacity Ownership.” IHS Markit, June 26, 2017. https://www.eia.gov/conference/2017/pdf/presentations/james_saeger.pdf

Shiller, R. 2003. "From Efficient Markets Theory to Behavioral Finance." Journal of Economics Perspectives 12 (1): 83-104. 
Sigrin, B., P. Sullivan, E. Ibanez, and R. Margolis. 2014. Representation of Solar Capacity Value in the ReEDS Capacity Expansion Model. NREL/TP-6A20-61182. Golden, CO: National Renewable Energy Laboratory.

Solar Foundation. 2017. National Solar Jobs Census 2016. Washington, DC: The Solar Foundation.

Strevel , N., L. Trippel, C. Kotarba, and I. Khan. 2014. "Improvements in CdTe Module Reliability and Long-Term Degradation through Advances in Construction and Device Innovation." Photovoltaics International 22.

https://www.cips.org/Documents/Knowledge/Categories-Commodities/BuyingEnergy/PVI_22_First_Solar_Reliability_WhitePaper_lowres.pdf

Trück, S., M. Laub, and S.T. Rachev. 2004. The Term Structure of Credit Spreads and Credit Default Swaps - an Empirical Investigation. Universität Karlsruhe.

U.S. Census Bureau. 2017. "Declining Mover Rate Driven by Renters, Census Bureau Reports." Accessed January 12, 2018, https://www.census.gov/newsroom/press-releases/2017/moverrates.html.

Wang, H., M. Liserre, F. Blaabjerg. 2014. "Transitioning to Physics-of-Failure as a Reliability Driver in Power Electronics." IEEE Journal of Emerging and Selected Topics in Power Electronics 2 (1): 97-114. 